\title{
Régimen jurídico y efectos de la declaratoria de invalidez de los contratos públicos en España
}

\author{
Marta Franch i Saguer ${ }^{1}$
}

\section{RESUMEN}

El artículo explora el régimen jurídico de la declaratoria de invalidez y de los efectos de la nulidad y anulabilidad de los contratos del sector público en España. Bajo el derecho español, la invalidez puede derivar de infracciones tanto del ordenamiento civil como del ordenamiento administrativo, y las consecuencias de su declaración comportan la nulidad o anulabilidad del acto. La materia de los contratos públicos registra una marcada influencia del derecho europeo, por lo que el presente trabajo examina también la forma en que las diferentes directivas europeas, entre ellas las de recursos, y la jurisprudencia del Tribunal de Justicia de la Unión europea modulan el régimen contractual nacional en materia de nulidades.

Palabras clave: contratos públicos, invalidez, nulidad absoluta, anulabilidad, efectos de la invalidez contractual.

1 Doctora en Derecho por la Universidad de Barcelona, Barcelona, España. Profesora de Derecho Administrativo de la Universidad Autónoma de Barcelona, Barcelona, España. Correo-e: Marta.Franch@uab.cat. Enlace ORCID: https://orcid.org/0000-0001-6768-0416. Fecha de recepción: 18 de agosto de 2020. Fecha de modificación: 20 de septiembre de 2020. Fecha de aceptación: 30 de septiembre de 2020. Para citar el artículo: FranCH I SAGUER, MARTA, "Régimen jurídico y efectos de la declaratoria de invalidez de los contratos públicos en España", Revista digital de Derecho Administrativo, Universidad Externado de Colombia, n. ${ }^{\circ} 25$, 2021, pp. 175-212. DoI: https://doi.org/10.18601/21452946.n25.06. 


\title{
Legal Regime and Effects of the Declaration of Invalidity of Public Contracts in Spain
}

\author{
ABSTRACT
}

This paper explores the legal regime of the declaration of invalidity and the effects of the nullity and voidability of public contracts in Spain. Under Spanish Law, the invalidity of contracts can derive from violations of both civil and administrative law. The consequences of the declaration of invalidity involve the absolute or relative nullity of the legal act. Due to the fact that the subject of Public Procurement is significantly influenced by European Law, the present work also examines the means by which different European directives, such as the one regulating resources, and the jurisprudence of the Court of Justice of the European Union, determine the Spanish regime of nullities in public contracts.

Keywords: Public Procurement, Legal Invalidity, Absolute Nullity, Relative Nullity, Effects of Contractual Invalidity.

\section{INTRODUCCIÓN}

El presente trabajo trata sobre las causas de invalidez de los contratos y de las consecuencias que tienen la declaración de nulidad y la anulabilidad de los mismos, así como los efectos que provocan. El estudio de este tema, dentro de la contratación y a través de numerosos ejemplos, nos llevará a concretar el régimen jurídico y las consecuencias de la invalidez en materia de contratación pública.

Conviene advertir al lector que el derecho europeo es de especial relevancia en la regulación de cada Estado miembro, sobre todo por el respeto a lo dispuesto en sus diferentes directivas. Entre estas encontramos la Directiva 2007/66/CE, que obliga a los Estados a establecer procedimientos de recursos en materia de adjudicación de contratos públicos. Esta obligación supone para España una revolución en materia de control de la contratación pública.

En el derecho español, la invalidez de los contratos viene determinada por dos factores. El primero consiste en que la nulidad y la anulabilidad están basados tanto en causas de derecho civil como en causas del derecho administrativo, y el segundo, en que la invalidez afecta tanto a los contratos públicos como a los privados que realicen los diferentes poderes adjudicadores. Como demostraremos a lo largo de este trabajo, la invalidez tiene especial trascendencia para la contratación pública, así como los efectos que produce y la reparación de los mismos. Advertimos también que, debido a la extensión del trabajo y sobre todo a las particularidades existentes en el régimen jurídico de la invalidez, habrá temas que serán tratados de forma general, en cuanto guarden relación con el objetivo aquí propuesto. 


\section{EL DERECHO EUROPEO EN MATERIA DE CONTRATOS}

El derecho de la contratación pública ha sufrido enormes cambios en los últimos años, que se han debido, en gran medida, a la incorporación de nuevas directivas al ordenamiento español y a la aplicación de la jurisprudencia europea, contenida tanto en condenas a Estados que han incumplido la transposición de las mismas, como en recomendaciones dirigidas y/o aplicables a España.

La normativa vigente en la actualidad está compuesta por las siguientes directivas:

- Directiva 2014/23/UE, del Parlamento Europeo y del Consejo, de 26 de febrero de 2014, relativa a la adjudicación de contratos de concesión.

- Directiva 2014/24/UE, del Parlamento Europeo y del Consejo, de 26 de febrero de 2014, sobre contratación pública y por la que se deroga la Directiva 2004/18/CE.

- Directiva 2014/25/UE, del Parlamento Europeo y del Consejo, de 26 de febrero de 2014, relativa a la contratación por entidades que operan en los sectores del agua, la energía, los transportes y los servicios postales, y por la que se deroga la Directiva 2004/17/CE.

Todas ellas fueron publicadas en el DOUE de 28 de marzo de 2014 y debían transponerse antes del 18 de abril de $2016^{[2]}$. España sin embargo las transpuso tarde, a través de la Ley 9/2017, de 8 de noviembre, de Contratos del Sector Público, por la que se transponen al ordenamiento jurídico español las directivas del Parlamento Europeo y del Consejo 2014/23/UE y 2014/24/UE, de 26 de febrero de 2014 (en adelante LCSP). Durante el periodo entre abril de 2016 y noviembre de 2018 se aplicaron directamente las directivas por falta de transposición.

La Comisión Europea decidió llevar a España, junto con otros países miembros de la UE, ante el Tribunal de Justicia de la Unión Europea (TJUE) por este grave incumplimiento en la transposición de las directivas. El TJuE ${ }^{3}$ sentó el principio según el cual los Estados miembros son responsables de los daños sufridos por los particulares a causa de no haber incorporado una directiva que puede ser invocada por ellos, sin que sea necesario que dichas disposiciones tengan efecto directo sobre los mismos. Las tres directivas modifican de forma importante la situación del régimen contractual anterior a las mismas. En este trabajo nos vamos a referir fundamentalmente a las dos primeras, ya que la última cubre sectores específicos.

Además de las directivas mencionadas, debemos referirnos también a la Directiva 2007/66/CE del Parlamento Europeo y del Consejo, de 11 de diciembre

2 La excepción a este plazo es la de la parte correspondiente a la incorporación del uso obligatorio de medios electrónicos en la contratación

3 Tribunal de Justicia de la Unión Europea, sentencia de 19 de noviembre de 1991, asuntos acumulados C-6/90 y C-9/90, Rec. 1991-I 5403. 
de 2007, por la que se modifican las directivas 89/665/CEE y 92/13/CEE del Consejo en lo que respecta a la mejora de la eficacia de los procedimientos de recurso en materia de adjudicación de contratos públicos. Estas directivas no tratan de forma directa sobre los vicios de los contratos, ni de las consecuencias de su infracción, pero sí establecen que las previsiones normativas que contienen deben ser respetadas en la legislación de cada Estado y que su infracción puede suponer la invalidez del procedimiento contractual o de su propia adjudicación. En este sentido, en la sentencia Brasserie du Pêcheur Factortame ${ }^{4}$ el TJuE reconoció la responsabilidad del Estado, en determinadas condiciones, por los daños causados por una infracción al derecho comunitario, protegiéndose, a través de esta responsabilidad, los derechos del ciudadano de una manera efectiva.

Es necesario recordar que las directivas, pero sobre todo la jurisprudencia europea, ha reconocido la existencia de un conjunto de principios generales de la contratación pública ${ }^{5}$, cuya infracción puede suponer la invalidez del contrato ${ }^{6}$.

De manera especial, hay que destacar que en la Directiva 2007/66/CE, tal y como se señala en su considerando tercero, se reforman las anteriores directivas 89/665/CEE y 92/13/CEE, ya que no siempre permitían "velar por el cumplimiento de la legislación comunitaria, en particular en una etapa en la que aún podrían corregirse las infracciones"7. En este orden de ideas, los Estados deben establecer un régimen especial de reclamaciones en materia de

Tribunal de Justicia de la Unión Europea, sentencia de 5 de marzo de 1996, asuntos acumulados C-46/93 y C-48/93, [1996] Rec I-1029. Véase también la sentencia British Telecom de 26 de marzo de 1996, asunto C-392/93, [1996] Rec I-I-1631.

5 Artículo 1 de la LCSP: "Objeto y finalidad. 1. La presente Ley tiene por objeto regular la contratación del sector público, a fin de garantizar que la misma se ajusta a los principios de libertad de acceso a las licitaciones, publicidad y transparencia de los procedimientos, y no discriminación e igualdad de trato entre los licitadores; y de asegurar, en conexión con el objetivo de estabilidad presupuestaria y control del gasto, y el principio de integridad una eficiente utilización de los fondos destinados a la realización de obras, la adquisición de bienes y la contratación de servicios mediante la exigencia de la definición previa de las necesidades a satisfacer, la salvaguarda de la libre competencia y la selección de la oferta económicamente más ventajosa".

6 Vicenç Aguado i Cudolà, "Efectos de la invalidez y prórroga de los contratos públicos", en Fernando López Ramón y Francisco Villar Rojas (coords.), El alcance de la invalidez de la actuación administrativa. Madrid: INAP, 2017, p. 226.

7 Asimismo, en el considerando $13 .^{\circ}$ se señala que: "Es para luchar contra la adjudicación directa ilegal, práctica que el Tribunal de Justicia ha calificado como la infracción más importante del derecho comunitario en materia de contratos públicos por parte de un poder adjudicador o entidad contratante, debe preverse una sanción efectiva, proporcionada y disuasoria. Por consiguiente, todo contrato derivado de una adjudicación directa ilegal debe considerarse en principio sin efectos. Esta falta de efectos no debe ser automática, sino que debe quedar sometida a la comprobación de un órgano de recurso independiente o derivar del resultado de una decisión de dicho órgano". 
procedimiento contractual ${ }^{8}$ para que los interesados puedan, a través de un procedimiento rápido, antes de que se adopte la adjudicación del contrato, obtener una decisión sobre las irregularidades que se hayan planteado durante las fases de preparación y adjudicación. Esto supone una obligada mejora de la eficacia de los recursos establecidos por los Estados y, de forma particular, la eficacia real de la resolución de los mismos ${ }^{9}$. Esta previsión ha transformado, como iremos viendo, el control de la preparación y adjudicación de los contratos. En la legislación española, el llamado recurso especial en materia de contratación está previsto y regulado en el capítulo quinto de la LCSP.

Fijémonos cómo en el considerando 21 de la Directiva de recursos se establece de forma clara cuál es el objetivo de este recurso:

El objetivo que se persigue al establecer los Estados miembros la normativa por la que se garantice que un contrato no produzca efectos, es que los derechos y las obligaciones de las partes del contrato dejen de ser de obligado cumplimiento y ejecución. Las consecuencias que se deriven de la ineficacia de un contrato deben quedar reguladas por la legislación nacional. Por tanto, la legislación nacional puede, por ejemplo, establecer la anulación de todas las obligaciones contractuales con efectos retroactivos (ex tunc) o limitarse a prever la anulación de aquellas obligaciones aún por ejecutar (ex nunc). Esto no debe implicar la falta de sanciones rigurosas si las obligaciones derivadas de un contrato se han cumplido ya parcial o casi totalmente. En estos casos, los Estados miembros deben prever también sanciones alternativas, teniendo en cuenta en qué medida el contrato sigue estando en vigor de conformidad con el derecho interno. De manera análoga, la legislación nacional determina las consecuencias relativas a la posible recuperación de cualquier importe ya abonado, así como todas las demás formas de restitución posible, incluida la restitución del valor cuando la restitución del bien no sea posible.

Asimismo, la Directiva 2007/66/CE deja a los Estados la posibilidad de regular las consecuencias de la infracción del derecho europeo. En este sentido, su artículo 2 establece que:

1. Los Estados miembros velarán por que las medidas adoptadas en relación con los procedimientos de recurso contemplados en el artículo 1 prevean las facultades necesarias para: a) adoptar, lo antes posible y mediante procedimiento de urgencia, medidas provisionales para corregir la infracción o para impedir que se causen otros perjuicios a los intereses afectados, incluidas las medidas destinadas a suspender o

8 José María Gimeno Feliú, "El nuevo sistema de recursos en materia de contratos públicos", en José María Gimeno Feliú (dir.), Observatorio de contratos públicos 2010, Cizur Menor: Civitas - Thomson-Reuters, 2011, pp. 211 a 258.

9 Tribunal de Justicia de la Unión Europea, sentencia de 6 de octubre de 2015, Orizzonte Salute, asunto C-61/14. JosÉ ANTONIO RAZQUIN, El impacto de la jurisprudència comunitària europea sobre los contratos púbicos (2003-2004) en el ordenamiento jurídico interno. Disponible en: file://C:/ Users/1000839/Downloads/RJ_37_II_2\%20(1).pdf [consultado el 8 de agosto de 2020]. 
a hacer que se suspenda el procedimiento de adjudicación del contrato público en cuestión o la ejecución de cualquier decisión adoptada por el poder adjudicador; b) anular o hacer que se anulen las decisiones ilegales, incluida la supresión de las características técnicas, económicas o financieras discriminatorias contenidas en los documentos de licitación, en los pliegos de condiciones o en cualquier otro documento relacionado con el procedimiento de adjudicación del contrato en cuestión; c) conceder una indemnización por daños y perjuicios a las personas perjudicadas por una infracción.

La Directiva deja a la legislación de cada país las consecuencias de la ineficacia de un contrato, así cada Estado "podrá establecer la anulación con efectos retroactivos de todas las obligaciones contractuales o limitar el alcance de la anulación a las obligaciones que estén aún por ejecutar" (artículo 2 quinquies). Dentro del ordenamiento español, esta previsión en el artículo 39.g de la LCSP es la que establece de forma clara que el "incumplimiento grave de normas de derecho de la Unión Europea en materia de contratación pública que conllevara que el contrato no hubiera debido adjudicarse al contratista, declarado por el TJUE en un procedimiento con arreglo al artículo 260 del Tratado de Funcionamiento de la Unión Europea"10. Por tanto, el incumplimiento del derecho europeo, ya sea en la regulación como en la propia aplicación, lleva a la invalidez del contrato.

\section{CAUSAS DE INVALIDEZ DE LOS CONTRATOS EN EL DERECHO ESPAÑOL}

La LCSP establece una serie de supuestos en los que los poderes adjudicadores en la celebración de los contratos pueden resultar inválidos ${ }^{11}$. Contrario a lo establecido anteriormente, la Ley de Contratos de 2017 establece un régimen de invalidez para todos los contratos celebrados por los poderes adjudicadores ${ }^{12}$

10 Artículo 260 del Tratado de Funcionamiento de la Unión Europea: "Si el Tribunal de Justicia de la Unión Europea declarare que un Estado miembro ha incumplido una de las obligaciones que le incumben en virtud de los Tratados, dicho Estado estará obligado a adoptar las medidas necesarias para la ejecución de la sentencia del Tribunal".

11 Juan Alfonso Santamaría Pastor, "La invalidez de los contratos públicos", en Rafael Gómez-Ferrer Morant (dir.), Comentarios a la Ley de Contratos de las Administraciones Públicas, $2{ }^{a}$ ed., Cizur Menor: Thomson-Civitas, 2004, pp. 365-396.

12 Artículo 3.2 de la LCSP "Se considerarán poderes adjudicadores, a efectos de esta Ley, las siguientes entidades: a) Las Administraciones Públicas: i. La Administración General del Estado, las Administraciones de las Comunidades Autónomas, las Ciudades Autónomas de Ceuta y Melilla y las Entidades que integran la Administración Local ${ }_{i}$ ii. Las Entidades Gestoras y los Servicios Comunes de la Seguridad Social ${ }_{i}$ iii. Los Organismos Autónomos, las Universidades Públicas y las autoridades administrativas independientes; iv. A los efectos de esta Ley, se entiende que también forman parte del sector público las Diputaciones Forales y las Juntas Generales de los Territorios Históricos del País Vasco en lo que respecta 
sin distinción. En este orden de ideas, están sujetos al régimen de invalidez previsto en la LCSP todos los contratos de las Administraciones públicas y de los poderes adjudicadores que no tengan la condición de Administraciones públicas, que son siempre contratos de derecho privado. También están sometidos a este régimen de invalidez los contratos subvencionados ${ }^{13}$.

La invalidez de los contratos está regulada en el capítulo IV de la LCSP, que le dedica seis artículos. Si bien es cierto que otras disposiciones de la LCSP hacen también referencia a diferentes infracciones al ordenamiento y a sus consecuencias jurídicas, en este capítulo no se está regulando la invalidez de los contratos como tal, sino únicamente la invalidez de los actos preparatorios y

a su actividad de contratación, v. Los consorcios y otras entidades de derecho público, en las que dándose las circunstancias establecidas en la letra d del apartado siguiente para poder ser considerados poder adjudicador y estando vinculados a una o varias Administraciones Públicas o dependientes de las mismas, no se financien mayoritariamente con ingresos de mercado. Se entiende que se financian mayoritariamente con ingresos de mercado cuando tengan la consideración de productor de mercado de conformidad con el Sistema Europeo de Cuentas; b) Las fundaciones públicas; c) Las Mutuas colaboradoras con la Seguridad Social ${ }_{i}$ d) Todas las demás entidades con personalidad jurídica propia distintas de las expresadas en las letras anteriores que hayan sido creadas específicamente para satisfacer necesidades de interés general que no tengan carácter industrial o mercantil, siempre que uno o varios sujetos que deban considerarse poder adjudicador de acuerdo con los criterios de este apartado 3, bien financien mayoritariamente su actividad ${ }_{i}$ bien controlen su gestión; o bien nombren a más de la mitad de los miembros de su órgano de administración, dirección o vigilancia ${ }_{i}$ e) Las asociaciones constituidas por las entidades mencionadas en las letras anteriores".

13 Artículo 23 de la LCSP: "Contratos subvencionados sujetos a una regulación armonizada 1. Son contratos subvencionados sujetos a una regulación armonizada los contratos de obras y los contratos de servicios definidos conforme a lo previsto en los artículos 13 y 17 , respectivamente, que sean subvencionados, de forma directa y en más de un 50 por 100 de su importe, por entidades que tengan la consideración de poderes adjudicadores, siempre que pertenezcan a alguna de las categorías siguientes:

a) Contratos de obras que tengan por objeto actividades de ingeniería civil de la sección F, división 45, grupo 45.2 de la Nomenclatura General de Actividades Económicas de las Comunidades Europeas (NACE), o la construcción de hospitales, centros deportivos, recreativos o de ocio, edificios escolares o universitarios y edificios de uso administrativo, siempre que su valor estimado sea igual o superior a 5.350.000 euros; b) Contratos de servicios vinculados a un contrato de obras de los definidos en la letra a), cuyo valor estimado sea igual o superior a 214.000 euros.

2. Las normas previstas para los contratos subvencionados se aplicarán a aquellos celebrados por particulares o por entidades del sector público que no tengan la consideración de poderes adjudicadores, en conjunción, en este último caso, con las establecidas en el Título II del Libro Tercero de esta Ley. Cuando el contrato subvencionado se adjudique por entidades del sector público que tengan la consideración de poder adjudicador, se aplicarán las normas de contratación previstas para estas entidades, de acuerdo con su naturaleza, salvo la relativa a la determinación de la competencia para resolver el recurso especial en materia de contratación y para adoptar medidas cautelares en el procedimiento de adjudicación, que se regirá, en todo caso, por la regla establecida en el apartado 2 del artículo $47^{\prime \prime}$. 
de adjudicación ${ }^{14}$, es decir, la invalidez de las diferentes actuaciones previas y de selección del contratista. En este sentido, la LCSP establece tres tipos de causas que provocan la invalidez y que se estudian a continuación.

\subsection{LAS CAUSAS DE INVALIDEZ PROCEDENTES DEL DERECHO CIVIL}

Las causas de invalidez de derecho civil son, como las causas de derecho administrativo, de nulidad o de anulabilidad. La nulidad absoluta se produce cuando falta alguno de los elementos esenciales del contrato. Está invalidez está prevista en el artículo 1261 del Código Civil (CC), que se refiere al consentimiento, objeto y causa del contrato, y también cuando el contrato sea contrario a normas imperativas o prohibitivas (artículos 6.3 y 1255 del CC) ${ }^{15}$.

En la sTs de la Sala $1 .{ }^{a}$ Civil de 10 de abril de $2001^{[16]}$ se explica la diferencia entre la nulidad radical y relativa:

en sede de ineficacia de los contratos resultan perfectamente diferenciables los conceptos de inexistencia o nulidad radical, de una parte, y de nulidad relativa o anulabilidad, de otra. En el primero se comprenden los supuestos en que o falta alguno de los elementos esenciales del contrato que enumera el artículo 1261 del Código Civil, o el mismo se ha celebrado vulnerando una norma imperativa o prohibitiva. El segundo se reserva para aquellos otros en que en la formación del consentimiento de los otorgantes ha concurrido cualquiera de los llamados vicios de la voluntad (error, violencia, intimidación o dolo).

La nulidad radical puede provenir de dos causas: la falta de alguno de los tres elementos esenciales del artículo 1261 del CC para que exista un contrato y que son el consentimiento, el objeto y la causa; y la vulneración de alguna norma imperativa o prohibitiva, ya que el artículo 6.3 del CC nos dice que "los actos contrarios a las normas imperativas y prohibitivas son nulos de pleno derecho, salvo que en ellas se establezca un efecto distinto para el caso de su contravención". Algunos ejemplos concretos pueden ilustrar estas causas, como ocurre con los contratos en los que su perfeccionamiento se produce

14 Carmen Alonso, Ley de contratos del sector público: Ámbito de aplicación. Modalidades contractuales y régimen de invalidez de los procedimientos de contratación, Barcelona: Fundación Democracia y Gobierno Local, 2009, pp. 63-118.

15 Artículo 1261 de la CC: "No hay contrato sino cuando concurren los requisitos siguientes: 1. ${ }^{\circ}$ Consentimiento de los contratantes. $2 .{ }^{\circ}$ Objeto cierto que sea materia del contrato. 3. ${ }^{\circ}$ Causa de la obligación que se establezca"; artículo 1255: "Los contratantes pueden establecer los pactos, cláusulas y condiciones que tengan por conveniente, siempre que no sean contrarios a las leyes, a la moral ni al orden público"; artículo 6: "3. Los actos contrarios a las normas imperativas y a las prohibitivas son nulos de pleno derecho, salvo que en ellas se establezca un efecto distinto para el caso de contravención".

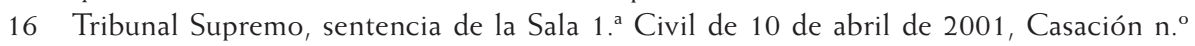
335/1996. 
con la adjudicación, y en donde la ausencia de oferta de una empresa provoca la nulidad por falta de consentimiento de la misma ${ }^{17}$. La falta de capacidad de obrar, en cambio, es al mismo tiempo una causa de nulidad de derecho civil como de derecho administrativo (artículo 39.2.a de la LCSP). Por ejemplo, el consentimiento en un contrato que fuese prestado por una persona incapaz se considera nulo. Dicha incapacidad debe ser declarada por sentencia judicial firme, conforme con lo dispuesto en el artículo 199 del CC ${ }^{18}$. La falta física del objeto del contrato también puede considerarse tanto una infracción dentro del ordenamiento civil como del administrativo. La diferencia con la situación anterior radica en que mientras que en el derecho civil esta infracción se sitúa dentro del grado de nulidad de pleno derecho, en el derecho administrativo se sitúa dentro de la anulabilidad del acto de adjudicación, de acuerdo con el artículo 40 de la LCSP. Con relación a la existencia o ilicitud de la causa del contrato, tenemos que es un supuesto que también puede asimilarse a la desviación de poder que es una de las causas de anulabilidad administrativa. Contrario a lo previsto en el Código Civil, este traería como consecuencia la nulidad. Otro supuesto de nulidad es que el contrato celebrado a nombre de otro, en el que falte la representación, será nulo, a no ser que lo ratifique la persona a cuyo nombre se otorgue antes de ser revocado por la otra parte contratante ${ }^{19}$.

Por lo demás, la STS de 23 de noviembre de $2016^{[20]}$ establece cuál es la situación de nulidad en la que se vulnera una norma imperativa o prohibitiva, al señalar que:

en primer lugar, el carácter imperativo para las partes de la limitación temporal establecida por la norma para el plazo del pago comporta que todos aquellos pactos que exceden de dicho límite temporal, 60 días naturales, resulten nulos de pleno derecho por contravención de lo dispuesto en la norma imperativa (artículo 6.3 del Código Civil) [...]. Por último, de acuerdo con lo señalado, el control de abusividad previsto en el artículo 9 LLCM ópera, necesariamente, dentro del plazo marcado por la limitación temporal establecido por la norma, pues más allá del mismo la sanción contemplada no es otra que la nulidad del pacto por ser contrario a la norma imperativa. Conclusión acorde tanto con la función tuitiva de la

17 Dictamen Consejo Estado n. ${ }^{\circ} 42123 / 1979$, de 29 de marzo de 1979

18 Artículo 199 de la CC: "Nadie puede ser declarado incapaz sino por sentencia judicial en virtud de las causas establecidas en la Ley".

19 Tribunal Supremo, sentencia de la Sala 1. ${ }^{a}$ Civil de 25 de junio de 2004, Casación n. ${ }^{\circ}$ 2302/1998: "el artículo 1259 del Código Civil declara la nulidad de los actos realizados por quién carece de autorización o representación legal de la persona a cuyo nombre contrata, pero esa nulidad no es absoluta, sino que puede ser neutralizada por la ratificación expresa o tácita del dominus negotii, confirmándose así el negocio (STS de 18 de marzo de 1999 y SSTS de 12 de junio de 1997)".

20 Tribunal Supremo, sentencia de la Sala 1. ${ }^{a}$ Civil de 23 de noviembre de 2016, Casación n. ${ }^{\circ} 2883 / 2014$ 
norma, como con la conveniencia de una interpretación que fije con claridad los criterios de aplicación normativa.

Para la declaración de nulidad de pleno derecho no hay plazo $^{21}$, a diferencia de la situación de nulidad relativa.

La nulidad relativa se produce en el derecho español cuando se dan vicios de error, dolo, intimidación o violencia en el consentimiento (artículo 1300 del CC), o la falta de capacidad natural del contratante (artículos 1262 y 1263 del (CC) ${ }^{22}$. La anulabilidad es lo mismo que la llamada nulidad relativa, en la que el negocio afectado puede convalidarse por confirmación o por caducar la acción. La situación del negocio jurídico, por tanto, puede oscilar entre ser válido o nulo definitivamente. La anulabilidad tiene un plazo de caducidad para ser alegada, que es de cuatro años (artículo 1301 del CC). La forma de empezar a contar el plazo depende de cada uno de los supuestos de anulabilidad. La nulidad relativa o anulabilidad se dará también en los casos previstos en el artículo 1265 del Código Civil que dice que "será nulo el consentimiento prestado por error, violencia, intimidación o dolo", a los que hay que sumar el previsto en el artículo 1259 del Código Civil que nos dice que: "Ninguno puede contratar a nombre de otro sin estar por este autorizado o sin que tenga por la Ley su representación legal. El contrato celebrado a nombre de otro por quien no tenga su autorización o representación legal será nulo, a no ser que lo ratifique la persona a cuyo nombre se otorgue antes de ser revocado por la otra parte contratante".

En primer lugar, para que se dé la situación del error en el consentimiento es necesario que exista o bien un error en la sustancia de la cosa que forme parte del objeto del contrato, o bien sobre las condiciones esenciales del mismo. Pueden existir errores de carácter subjetivo, en este supuesto solamente se

21 Tribunal Supremo, Sentencias de la Sala $1 .{ }^{\circ}$ Civil de 14 de marzo de 2000, casación n. ${ }^{\circ}$ 1724/1995 y de 25 de marzo de 2002, casación n. ${ }^{\circ}$ 3159/1999.

22 Artículo 1262 de la CC: "El consentimiento se manifiesta por el concurso de la oferta y de la aceptación sobre la cosa y la causa que han de constituir el contrato. Hallándose en lugares distintos el que hizo la oferta y el que la aceptó, hay consentimiento desde que el oferente conoce la aceptación o desde que, habiéndosela remitido el aceptante, no pueda ignorarla sin faltar a la buena fe. El contrato, en tal caso, se presume celebrado en el lugar en que se hizo la oferta. En los contratos celebrados mediante dispositivos automáticos hay consentimiento desde que se manifiesta la aceptación".

Artículo 1263 de la CC: "No pueden prestar consentimiento: $1 .{ }^{\circ}$ Los menores no emancipados, salvo en aquellos contratos que las leyes les permitan realizar por sí mismos o con asistencia de sus representantes, y los relativos a bienes y servicios de la vida corriente propios de su edad de conformidad con los usos sociales. $2 .{ }^{\circ}$ Los que tienen su capacidad modificada judicialmente, en los términos señalados por la resolución judicial".

Artículo de la 1300 CC: "Los contratos en que concurran los requisitos que expresa el artículo 1.261 pueden ser anulados, aunque no haya lesión para los contratantes, siempre que adolezcan de alguno de los vicios que los invalidan con arreglo a la ley". 
daría la situación de invalidez del contrato cuando el elemento personal fuera un elemento esencial en el consentimiento para contratar (artículo 1266 del CC). Esta situación hay que diferenciarla de la falta de consentimiento que supone la su nulidad radical ${ }^{23}$.

Para que exista violencia en el consentimiento es necesario que se hubiere empleado una fuerza irresistible con el objeto de provocar el mismo. Para que se dé la intimidación es además indispensable que se provoque a uno de los contratantes un temor racional y fundado de sufrir un mal inminente y grave en su persona o bienes, o en la persona o bienes de su cónyuge, descendientes o ascendientes. El temor de desagradar a las personas a quienes se debe sumisión y respeto no es una causa para poder anular el contrato ${ }^{24}$.

Con relación a los sujetos legitimados para ejercer la acción de nulidad, el artículo 1302 del Código Civil establece que "Pueden ejercitar la acción de nulidad de los contratos los obligados principal o subsidiariamente en virtud de ellos. Las personas capaces no podrán, sin embargo, alegar la incapacidad de aquellos con quienes contrataron; ni los que causaron la intimidación o violencia, o emplearon el dolo o produjeron el error, podrán fundar su acción en estos vicios del contrato".

Numerosas sentencias tratan de la invalidez de los contratos por las causas previstas en el Código Civil ${ }^{25}$. La invalidez por causas de derecho civil está sujeta a los "requisitos y plazos de ejercicio de las acciones establecidos en el ordenamiento civil, pero el procedimiento para hacerlas valer, cuando el contrato se haya celebrado por una Administración pública, se someterá a lo

Tribunal Supremo, sentencia de la Sala 1. a de 10 de abril de 2001, Casación n. ${ }^{\circ}$ 335/1996

Artículos 1.267 y 1.268 de la CC. Tribunal Supremo, sentencia de la Sala $1 .{ }^{a}$ Civil de 31 de octubre de 1994 y de 4 de octubre de 2002, recurso 980/1997; MARía CONCEPCIÓn CAMPOS ACuÑa, La nueva contratación pública en el ámbito local, Madrid: Editorial El Consultor de los Ayuntamientos, 2018; p. 195; en un mismo sentido, Valentín Carrascosa López, Asunción Pozo Arranz y Eduardo Rodríguez de Castro, "El consentimiento y sus vicios en los contratos perfeccionados a través de medios electrónicos", Informática y Derecho. Revista Iberoamericana de Derecho Informático, n. ${ }^{\circ} 12-15.1996$, p. 1029.

25 Tribunal Supremo, sentencia de 23 de noviembre de 2016, Casación n. ${ }^{\circ}$ 2883/2014; Nulidad civil por infracción de normas imperativas, en un mismo sentido: Tribunal Supremo, sentencia de 2 de noviembre de 2015, Casación n. ${ }^{\circ}$ 2506/2014: Nulidad por introducción de cláusulas abusivas; Tribunal Supremo, sentencia de la Sala 1. a de 10 de abril de 2001, Casación n. ${ }^{\circ}$ 335/1996: Error obstativo civil ${ }_{i}$ Tribunal Supremo, sentencias de la Sala 1. ${ }^{a}$ Civil de 31 de octubre de 1994 y de 4 de octubre de 2002, recurso 980/1997. Nulidad relativa por violencia o intimidación civiles; Tribunal Supremo, sentencia de la Sala $1 .{ }^{a}$ Civil de 27 de noviembre de 1998, Casación n. ${ }^{\circ}$ 1257/1994: Dolo civil, Tribunal Supremo, sentencia de la Sala $1 .{ }^{\text {a Civil de }} 25$ de junio de 2004, Casación n. ${ }^{\circ}$ 2302/1998 y sentencia de 3 de diciembre de 2001, Casación n. ${ }^{\circ}$ 2365/1996: Nulidad artículo 1.259 de la CC; Tribunal Supremo, sentencia de la Sala $1 .{ }^{a}$ Civil de 14 de marzo de 2000, Casación n. ${ }^{\circ}$ 1724/1995 y de 25 de marzo de 2002, recurso 3159/1999: No plazo en nulidad radical civil $_{i}$ Tribunal Supremo, sentencia de la Sala $1 .{ }^{a}$ Civil de 26 de julio de 2000, Casación n. ${ }^{\circ}$ 2925/1995: Efectos nulidad civil. 
previsto en los artículos anteriores para los actos y contratos administrativos anulables (artículo 43 de la LCSP). Según Tardío, "en derecho civil, la auténtica diferencia entre la nulidad de pleno derecho y la anulabilidad no reside en los efectos de su declaración (dando lo mismo que se considere de carácter declarativo o constitutivo), sino en el sometimiento a plazo de la acción y restricción de la misma a la persona que ha sufrido el vicio o padece la restricción a su capacidad de obrar, en el caso de la anulabilidad (mientras que no hay plazo ni restricción de legitimación activa en la nulidad de pleno derecho) y, por eso, también se admite su confirmación o convalidación" ${ }^{\prime 26}$.

\subsection{LAS CAUSAS DE INVALIDEZ PROCEDENTES DEL DERECHO ADMINISTRATIVO}

Para comenzar vamos a diferenciar entre las causas de nulidad y anulabilidad en el ámbito de lo civil y del ámbito administrativo, tal como lo establece la STS 5082/2010, 11 de enero de 2013 $3^{[27]}$. De acuerdo con la sentencia del Tribunal Supremo, el régimen jurídico y las consecuencias de la invalidez no son iguales en el derecho civil y en el derecho administrativo. En este punto abordaremos el estudio específico de la invalidez de los contratos en el ámbito administrativo.

Antes de entrar en materia quisiéramos analizar brevemente el concepto de invalidez, partiendo de que este concepto nace del análisis de si un acto administrativo, dictado por la Administración, bajo los privilegios de la autotutela declarativa y ejecutiva, es conforme o no al ordenamiento jurídico. Cuando este acto no es conforme se declara por la Administración, por el juez o por el tribunal competente su nulidad o anulabilidad. Se trata de una aplicación del principio de legalidad, el más importante del derecho administrativo, al acto administrativo concreto. Toda actividad, y no solo la actividad contractual, debe ser ajustada al derecho, ya que de lo contrario comporta una

26 José Antonio Tardío Pato, "Los efectos ex tunc de la anulabilidad", Revista Española de Derecho Administrativo, $\mathrm{n}^{\circ} 184,2017$, p. 15.

27 Tribunal Supremo, sentencia de la Sala de lo contencioso administrativo, de 11 de enero de 2013, Casación núm. 5082/2010. Al respecto, esta jurisprudencia señala que: "En primer lugar en el orden civil la regla general es la nulidad, mientras que en el administrativo es la excepción, reservada a los casos más graves del ordenamiento jurídico (artículos 62 y 63 de la Ley 30/1992, antes citada). Que, aunque no exista plazo para reclamar en ambos ámbitos ordinamentales, este puede ser moderado en vía administrativa, en virtud del artículo 106 de la última norma citada. Que al contrario de lo ocurre en la vía civil, en cuanto a la retroactividad, que no se produce en la anulación, sino desde el ejercicio de la acción, en la jurisdicción contencioso-administrativa, el reconocimiento de la situación jurídica individualizada (artículo 31.2 de la Ley Reguladora de la Jurisdicción ContenciosoAdministrativa), hace que también en la anulación los efectos se retrotraigan al momento anterior a la resolución impugnada. En consecuencia, aquí se ha declarado la nulidad de un contrato administrativo por la aplicación del artículo 62.1 de la Ley 30/1992, y los efectos jurídicos de dicha declaración de nulidad han de extraerse, no de la legislación civil, sino de la Administrativa". 
antijuridicidad, una irregularidad y un vicio con unas consecuencias jurídicas que dependen del grado de la infracción. La infracción más grave lleva a la nulidad y la menos grave a la anulabilidad. Si la infracción no está en ninguno de los supuestos previstos en la Ley de Procedimiento Administrativo Común y de las Administraciones Públicas (LPAC), o en nuestro caso de la LCSP, no tendrá consecuencias y estaremos ante un supuesto de irregularidad no invalidante ${ }^{28}$.

La LPAC, en su artículo 47, señala cuáles son los supuestos de nulidad y, como ha dicho la jurisprudencia, deben interpretarse de forma restrictiva. Los supuestos de anulabilidad están determinados en el artículo 48 y tienen un carácter abierto, ya que, como dispone el propio precepto, se trata de actos que infringen el ordenamiento jurídico. Pero la distinción más importante viene de su diferente régimen jurídico. Mientras que los actos nulos no son convalidables $^{29}$, los anulables sí que lo son. Otra diferencia es que para los actos nulos no hay plazo para restablecer la legalidad, de aquí la posibilidad de la revisión de oficio, ya que el bien que se protege es la legalidad y su restablecimiento (artículo 197 de la LPAC). Por el contrario, la anulabilidad sí que tiene plazo, ya sea el del recurso administrativo o contencioso o los cuatro años del procedimiento de declaración de lesividad. Otro de los elementos a tener en cuenta son los efectos, de tal manera que la nulidad produce efectos ex tunc, mientras que la anulabilidad tiene efectos ex nunc. Sin embargo, esta distinción no se da siempre, como veremos en el ámbito de la contratación ${ }^{30}$.

RTACRC $n{ }^{\circ}{ }^{3} 389 / 2017$ de 28 de abril cuando dice: "sobre el incumplimiento de los plazos para adjudicar el contrato que contiene tanto el TRLCSP en su artículo 151 como la cláusula 16.1 del PCAP que rige la licitación del Acuerdo Marco objeto de este recurso, debe señalarse que, no conteniendo la normativa de contratos previsión alguna que permita concluir la invalidez del acuerdo de adjudicación finalmente adoptado por haber sido dictado más allá del plazo legalmente previsto, resulta de aplicación la regla general contenida en la Ley de Procedimiento Administrativo 39/2015 que, con idéntico criterio que el recogido en la ya derogada Ley 30/1992, reitera la regla general (artículo 48.3) en cuya virtud 'La realización de actuaciones administrativas fuera del tiempo establecido para ellas solo implicará la anulabilidad del acto cuando así lo imponga la naturaleza del término o pla$z^{\prime}$ '. A ello debe añadirse que si el propio legislador permite al órgano de contratación, dictado el acuerdo de adjudicación, incumplir el plazo de formalización del contrato sin más efecto que el de indemnizar al adjudicatario por los daños y perjuicios causados, para el caso de que el retraso haya sido imputable a la Administración con mayor motivo habrá de concluirse el carácter no esencial del plazo previsto en el artículo 151 TRLCSP para que el órgano de contratación dicte acuerdo de adjudicación, de modo que de su incumplimiento no derive un defecto invalidante de dicho acuerdo".

29 Tribunal Supremo, sentencia de 19 de febrero de 2008, Casación n. ${ }^{\circ}$ 43/2006: Actos nulos no cabe convalidación.

30 Alfredo Gallego Anabitarte y Ángel Menéndez ReXach, Acto y procedimiento administrativo, Madrid: Marcial Pons, 2001, p. 195; también consultar, Silvia Diez SASTRE, "Los efectos de la invalidez en los procedimientos de adjudicación de contratos públicos", en Fernando López Ramón y Francisco Villar (eds.), El alcance de la invalidez de la actuación administrativa, Madrid: INAP, 2017. 
a. Nulidad: La nulidad absoluta es la consecuencia de una infracción muy grave del ordenamiento $y$, por tanto, resulta ser imprescriptible, insubsanable e indisponible por el particular. Los diferentes supuestos de nulidad se encuentran previstos en el artículo 39 de la LCSP, entre los cuales encontramos los indicadas en el artículo 47 de la Ley 39/2015, del Procedimiento Administrativo Común y de las Administraciones Públicas, así como la nulidad de pleno derecho de los contratos celebrados por poderes adjudicadores en los que concurra alguna de las causas que presentamos a continuación:

La falta de capacidad de obrar o de solvencia económica, financiera, técnica o profesional es una primera causal prevista en la ley. A esta se suma la falta de habilitación empresarial o profesional cuando la misma sea exigible para la realización de la actividad o prestación que constituya el objeto del contrato. Asimismo, se incluye dentro de esta primera causal la falta de clasificación, cuando esta proce$\mathrm{da}$, debidamente acreditada, del adjudicatario; o el estar este incurso en alguna de las prohibiciones para contratar señaladas en el artículo 71 de esa misma ley.

Luego encontramos como causal de nulidad la carencia o insuficiencia de crédito, de conformidad con lo establecido en la Ley 47/2003, General Presupuestaria, o en las normas presupuestarias de las restantes Administraciones públicas que están sujetas a dicha ley, salvo los supuestos de emergencia.

En relación con el proceso, se tiene que la falta de publicación del anuncio de licitación en el perfil de contratante alojado en la Plataforma de Contratación del Sector Público o en los servicios de información similares de las comunidades autónomas, en el Diario Oficial de la Unión Europea o en el medio de publicidad en que sea preceptivo, es también una casual de nulidad. Esto también ocurre en los caso en que no se menciona en los pliegos lo previsto en los párrafos tercero, cuarto y quinto del apartado 2 del artículo 122 de la LCSP.

A su vez, la inobservancia por parte del órgano de contratación del plazo para la formalización del contrato es también susceptible de acarrear la nulidad del contrato, siempre que concurran los dos siguientes requisitos: a) que por esta causa el licitador se hubiese visto privado de la posibilidad de interponer recurso contra alguno de los actos del procedimiento de adjudicación; y b) que, además, concurra alguna infracción de los preceptos que regulan el procedimiento de adjudicación de los contratos que le hubiera impedido obtener esta.

La norma también señala como causal de nulidad haber llevado a efecto la formalización del contrato, en los casos en que se hubiese interpuesto el recurso especial en materia de contratación, sin respetar la suspensión automática del acto recurrido en los casos en que fuera procedente, o la medida cautelar de suspensión acordada por el órgano competente para conocer del recurso especial en materia de contratación que se hubiera interpuesto.

En cuanto a los incumplimientos de las disposiciones en materia de contratación, se establece que el incumplimiento de las normas establecidas para la adjudicación de los contratos basados en un acuerdo marco celebrado con varios empresarios o de los contratos específicos basados en un sistema 
dinámico de adquisición en el que estuviesen admitidos varios empresarios es también causal de nulidad del contrato, siempre que dicho incumplimiento hubiera determinado la adjudicación del contrato de que se trate a otro licitador. En un mismo sentido, el incumplimiento grave de normas de derecho de la Unión Europea en materia de contratación pública, lo que conduce a que el contrato no hubiera debido adjudicarse al contratista, declarado por el TJuE en un procedimiento con arreglo al artículo 260 del Tratado de Funcionamiento de la Unión Europea, genera la nulidad del contrato.

Como podemos ver, el primer supuesto de nulidad es una remisión a las causas generales del artículo 47 de la LPAC $^{31}$. En este artículo se establece que son nulos de pleno derecho los actos de las Administraciones públicas en los casos siguientes:

a) Los que lesionen los derechos y libertades susceptibles de amparo constitucional.

b) Los dictados por órgano manifiestamente incompetente por razón de la materia o del territorio.

c) Los que tengan un contenido imposible.

d) Los que sean constitutivos de infracción penal o se dicten como consecuencia de esta.

e) Los dictados prescindiendo total y absolutamente del procedimiento legalmente establecido o de las normas que contienen las reglas esenciales para la formación de la voluntad de los órganos colegiados.

f) Los actos expresos o presuntos contrarios al ordenamiento jurídico por los que se adquieren facultades o derechos cuando se carezca de los requisitos esenciales para su adquisición.

g) Cualquier otro que se establezca expresamente en una disposición con rango de Ley.

2. También serán nulas de pleno derecho las disposiciones administrativas que vulneren la Constitución, las leyes u otras disposiciones administrativas de rango superior, las que regulen materias reservadas a la Ley, y las que establezcan la retroactividad de disposiciones sancionadoras no favorables o restrictivas de derechos individuales.

31 Javier García Luengo, "Los supuestos de nulidad de peno derecho establecidos al margen de la ley de procedimiento administrativo común", RAP, n. ${ }^{\circ} 159$, 2002, pp. 137-172; es también posible consultar: MARGarita Beladiez Rojo, Validez y eficacia de los actos administrativos, Madrid: Marcial Pons, 1994. 
Numerosos ejemplos reflejan estas causas de nulidad, en especial las contenidas en las resoluciones de los diferentes tribunales administrativos de recursos contractuales ${ }^{32}$ y las sentencias de la jurisdicción contenciosa, también las resoluciones de las revisiones de oficio. Vamos a ver algunos ejemplos de resoluciones de nulidad de contratos por infracción del artículo $47^{[33]}$. Es posible indicar la reciente Resolución 861/2019 del Tribunal Administrativo Central de Recursos Contractuales (TACRC), que declara nula de pleno derecho la adjudicación del contrato por tratarse de un acto de contenido imposible (artículo 47.1.c de la LPAC) ${ }^{34}$. En la misma línea de nulidad por falta de motivación, la Resolución 34/2016 de 22 de enero resuelve que la indefinición de la motivación de la utilización del procedimiento negociado sin publicidad determina la nulidad de la totalidad del procedimiento de contratación, debiendo volver a convocarse la correspondiente licitación o la falta de una negociación verdadera y efectiva también determina la nulidad ${ }^{35}$.

32 La Sentencia del Tribunal Supremo de 13 de febrero de 1998 (Aranzadi 2184) recuerda la importancia de que esta incompetencia sea manifiesta, es decir, que no requiera de esfuerzos dialécticos o interpretaciones jurídicas para detectarla. Véanse también: Tribunal Supremo, sentencia de 30 de junio de 1997 (Aranzadi 5433); Tribunal Supremo, sentencia de 15 de octubre de 1997 (Aranzadi 7457). Tribunal Supremo, sentencia de 16 de junio de 1998 (Aranzadi 6322); Tribunal Supremo, sentencia de 31 de enero de 1994 (Aranzadi 504).

33 Tribunal Supremo, sentencia de 22 de junio de 2016, Casación n. ${ }^{\circ}$ 1636/2015 o la resolución del Tribunal Administrativo Central de Recursos Contractuales n. ${ }^{\circ} 444 / 2013$, de 10 de octubre y n. ${ }^{\circ}$ 103/2016, de 4 de marzo: Nulidad letra a) artículo 47.1 de la LAPC. En un mismo sentido: Tribunal Supremo, sentencia de 12 de abril de 2004, Casación n. ${ }^{\circ}$ 683/1998: Nulidad letra b) artículo 47.1 de la LPAC; Tribunal Supremo, sentencia de 21 de junio de 1994, Casación n. ${ }^{\circ}$ 3558/1990: Nulidad letra c) artículo 47.1 de la LPAC; Tribunal Supremo, sentencia de la Sala 2. ${ }^{a}$ de 5 de abril de 2002, Casación n. ${ }^{\circ}$ 494/2001: Nulidad letra d) artículo 47.1 de la LPAC; Tribunal Supremo, sentencia de 23 de mayo de 2012, Casación n. ${ }^{\circ} 7113 / 2010$ : Nulidad letra e) artículo 47.1 de la LPAC; Tribunal Supremo, sentencia de 30 de diciembre de 2008, Casación n. ${ }^{\circ}$ 5885/2006: Nulidad letra f) artículo 47.1 de la LPAC; Tribunal Supremo, sentencia de 2 de octubre de 2000, Casación n. ${ }^{\circ}$ 1546/1995: Falta clasificación contratista causa de nulidad. Consultar además la obra de CARLOS AYMERICH CANO, Un problema pendiente: la anulación de los contratos administrativos afectados por actos de corrupción, Cizur Menor: Thomson-Reuters, Aranzadi, 2015, p. 15.

34 El TACRC aprecia la existencia de esta causa nulidad del acto de adjudicación del contrato, ya que la: "oferta presentada en este aspecto un acto fraudulento e imposible de cumplir, la aceptación por la Administración de la oferta presentada y la consiguiente adjudicación del contrato, implica un supuesto de nulidad de pleno derecho encuadrable dentro del art. 47,1 c) de la Ley 39/2015 como acto de 'contenido imposible', e incursa en causa de nulidad de Derecho Civil en cuanto servicio imposible que no puede ser objeto de contrato (artículo 1.262 del CC en relación con el artículo 43 de la LCSP), ni por ello aceptada dicha oferta, que debe determinar su anulación con independencia de que el Pliego no haya sido previamente impugnado, pues la imposibilidad de cumplimiento de la oferta debe determinar por sí sola la anulación de la adjudicación efectuada".

35 El TARC considera que la negociación ha de ser verdadera y efectiva, con todos los candidatos, pues el trato no igualitario la viciaría de nulidad de pleno derecho (resoluciones 50/2011, $69 / 2016$ y 426/2016, entre otras). Dado que en el negociado no hay estrictamente una 
De igual modo, el TACRC considera que, en un procedimiento negociado, esa negociación precisamente ha de ser verdadera y efectiva, con todos los candidatos, pues el trato no igualitario la viciaría de nulidad de pleno dere$\mathrm{cho}^{36}$. Dado que en el negociado no hay estrictamente una licitación, propia del procedimiento abierto, la presentación de ofertas no puede considerarse una fase de negociación, que siempre será posterior. Si falta la negociación, la adjudicación deberá ser anulada por incumplimiento de un trámite esencial del procedimiento negociado ${ }^{37}$.

De nuevo encontramos en las resoluciones de los órganos encargados de resolver los recursos especiales más supuestos en los que no cumplir la exigencia de motivación de la adjudicación supone la nulidad de la resolución de adjudicación si falta motivación ${ }^{38}$. En los acuerdos 5/2011 y 10/2011 del Tribunal Administrativo de Contratos Públicos de Aragón se establece que la discrepancia entre la información contenida en los pliegos y en los anuncios determinará por sí sola la nulidad de los pliegos por contener incongruencias que impidan conocer con claridad cuáles son las condiciones básicas del

licitación, propia del procedimiento abierto, la presentación de ofertas no puede considerarse una fase de negociación, que siempre será posterior. Si falta la negociación, la adjudicación deberá ser anulada por incumplimiento de un trámite esencial del procedimiento negociado (resoluciones 301/2014, 231/2013 y 50/2011). Así el Tribunal dice: "De todo lo expuesto resulta que se ha producido una utilización inadecuada del procedimiento negociado sin publicidad que determina la nulidad de pleno derecho de dicho procedimiento al haberse utilizado a pesar de haberse introducido una modificación sustancial respecto del procedimiento anterior $y$, además, al fundamentarse en el apartado a) del artículo 44.2 de la Ley 11/2011 invitando tan sólo a los dos licitadores del procedimiento anterior en lugar de solicitar al menos tres ofertas tal como ordena el artículo 46 de la citada Ley para los supuestos en que resulte de aplicación el apartado a) del citado precepto legal. Octavo. La utilización de un procedimiento negociado sin publicidad afecta al cumplimiento del requisito de publicidad de la licitación, extremo éste que es de orden público, de forma que su cumplimiento puede ser apreciado de oficio por este Tribunal. En consecuencia, procede la anulación de la totalidad del procedimiento de contratación, debiendo volver a convocarse la correspondiente licitación".

36 Tribunal Administrativo Central de Recursos Contractuales, resoluciones 50/2011, 69/2016 y 426/2016, entre otras.

37 Tribunal Administrativo Central de Recursos Contractuales, resoluciones 301/2014 $231 / 2013$ y $50 / 2011$.

38 Tribunal Supremo, sentencia de 30 de mayo de 2000, estimándose el recurso Contencioso-Administrativo por esta causa; Tribunal Supremo, sentencia de 27 de marzo de 2001; Tribunal Supremo, sentencia de 7 de octubre de 1999; Tribunal Supremo, sentencia de 29 de junio de 1999; Tribunal Supremo, sentencia de 31 de octubre de 1994; Tribunal Supremo de Justicia de la Comunidad Valenciana, sentencia de 21 de abril de 2006 JuR 262197; Tribunal Administrativo Central de Recursos Contractuales en su Resolución número 34/2016, al señalar que la indefinición en cuanto a la motivación de la utilización de este procedimiento determina la nulidad de todo el procedimiento de contratación, debiendo volver a convocarse la correspondiente licitación. 
contrato $^{39}$. En este mismo sentido, también en el recurso 370/2014 del TACRC se reafirma el criterio ya consolidado de numerosas resoluciones ${ }^{40} \mathrm{y}$ del propio TJUE, ya que en la sentencia de este órgano de 16 de octubre de 2003 (asunto Trunfelher GMBH) se resalta "la obligación de que el pliego de cláusulas detalle las condiciones y requisitos de presentación de las mejoras, en aras del principio de igualdad de los licitadores". Esta concreción también se exige "para la valoración de las ofertas, que incluye la de las mejoras, su concreción es un requisito esencial, pues como ha recordado la sentencia TJuE de 28 de noviembre de 2008, el órgano de valoración no puede establecer a posteriori coeficientes de ponderación, subcriterios o reglas no reflejados en el pliego". En el evento en el que no se determine en el pliego la forma de acreditar y valorar las mejoras, y estas sirvan como criterio de adjudicación, lo que procede es declarar nula la cláusula contenida en el pliego, extendiéndose esta nulidad a todo el procedimiento, toda vez que se afecta directamente un principio de la contratación que determinó los criterios de adjudicación.

Citamos también, a forma de ejemplo, un dictamen, de los muchos que hay, sobre nulidad de la contratación verbal ${ }^{41}$. Así, el Dictamen 0384/2020 de 8 de julio del 2020 del Consejo Consultivo de Andalucía ante una contratación verbal resuelve:

En cuanto al fondo del asunto, se propone la nulidad del encargo de los servicios prestados por concurrir la causa de nulidad prevista en la letra e) del apartado 1 del artículo 47 de la Ley 39/2015, consistente en haberse prescindido total y absolutamente del procedimiento legalmente establecido [...]. Eso significa que estamos ante una contratación verbal prohibida por la normativa vigente aplicable (artículos 28.1 del TRLCSP), salvo que hubiese procedido la contratación de emergencia, como esos mismos preceptos señalan, que claramente no operaba en el presente caso pues conforme al artículo 113.1 del TRLCSP solo sería posible "cuando la Administración tenga que actuar de manera inmediata a causa de acontecimientos catastróficos, de situaciones que supongan grave peligro o de necesidades que afecten a la defensa nacional". Por tanto, es claro que concurre la causa de nulidad prevista en la letra

39 Acuerdos 5/2011 y 10/2011, del Tribunal Administrativo de Contratos Públicos de Aragón. La discrepancia entre la información contenida en los pliegos y en los anuncios determinará por sí sola la nulidad de los pliegos por contener incongruencias que impidan conocer con claridad cuáles son las condiciones básicas del contrato.

40 Las resoluciones 514/2013 de 14 de noviembre, 207/2013 de 5 de junio, 302/2011 14 de diciembre, 189/2011 de 20 de julio, 180/2013 de 23 de mayo de 2013 dictada en el recurso 187/2013, 155/2011 69/2012 y la 203/2012.

41 EVA SOlER MIfSUD, La contratación verbal en la administración local: Efectos, procedimiento a seguir, y responsabilidades que pueden derivarse. Posible incidencia sobre la ley de transparencia y especial referencia a la Agencia de Prevención y Lucha contra el Fraude de la Comunidad Valencia. Auditoría Pública 70, 2017. Disponible en: https://asocex.es/la-contratacion-verbal-en-la-administracionlocal-efectos-procedimiento-a-seguir-y-responsabilidades-que-pueden-derivarse-posibleincidencia-sobre-la-ley-de- [consultado el 10 de agosto de 202]. 
e) del artículo 47.1 de la Ley 39/2015, consistente en que se haya prescindido total y absolutamente del procedimiento legalmente establecido para ello.

Conviene también destacar la Resolución 00378/2012 de 20 de enero de 2012 Rec. 11-04420/2011, del Tribunal Administrativo de Navarra, Sección 2. ${ }^{\text {, }}$ Nulidad de constitución y actuación de la Mesa de Contratación, en donde se señala la necesidad de la presencia del secretario o suplente por delegación, y como su ausencia comporta la nulidad de pleno derecho, vulneración de las normas esenciales para la formación de la voluntad del órgano colegiado.

Numerosa jurisprudencia completa los supuestos de declaración de nulidad. Así, para empezar, la STS de 30 de abril de $2015^{[42]}$ atribuye la consecuencia de la nulidad en un supuesto en el que existe un delito de prevaricación administrativa consistente en fraccionar el objeto del contrato para utilizar el procedimiento negociado, eludiendo el procedimiento abierto. Podemos continuar con otra sentencia del Tribunal Supremo de 18 de julio de 1991 en la que se declara la nulidad de un contrato por celebrarse con contratista incurso en prohibición de contratar. O en la STS de 2 de noviembre de $2015^{[43]}$, en la que se confirma que la inclusión de la obligación del contratista de conceder un crédito a la Administración que le adjudica el contrato es abusiva por entrar dentro de los supuestos de nulidad y abusividad previstos en el artículo 9 de la Ley 3/2004 de 29 de diciembre, por la que se establecen medidas de lucha contra la morosidad en las operaciones comerciales.

Incluso más allá va la STS del País Vasco n. ${ }^{\circ}$ 519/2015, de 14 de diciembre, que anula la contratación de un "servicio de colaboración en la inspección y gestión tributaria" en el Ayuntamiento de Amurrio. Ello se debe a que las tareas de "colaboración, proposición, instrucción y tramitación" en dichos expedientes también comportan la participación, aunque más indirecta, en el "ejercicio de la autoridad inherente a los poderes públicos" ${ }^{44}$.

Otro supuesto de nulidad del artículo 47 de la LCSP es el que establece la STS (C-A) de 3 de noviembre de 2004, en la que se precisa la función básica de que

42 Tribunal Supremo, sentencia de la Sala $1{ }^{a}{ }^{a}$ Civil, del 30 de abril de 2015, recurso n. ${ }^{\circ}$ 929/2013

43 Tribunal Supremo, sentencia de la Sala Tercera de lo contencioso administrativo, de 2 de noviembre de 2015, Casación n. ${ }^{\circ}$ 2506/2014.

44 De igual manera, nuestro Tribunal Supremo, en Sentencia de 20 de noviembre de 2009, Recurso de Casación 520/2007, hace eco de la relevancia del secreto de las proposiciones, diciendo que: "se trata de garantizar no solo la igualdad entre los licitadores sino también de evitar que el poder adjudicador, o administración contratante, conozca su contenido con anterioridad al acto formal de apertura de las ofertas favoreciendo una determinada adjudicación en razón a ese conocimiento previo. Mediante tal exigencia se pretende que el proceso sea objetivo y desarrollado con absoluta limpieza sin interferencias. Por ello, cuando se quebranta el secreto de la proposición la nulidad del procedimiento constituye la consecuencia inevitable, tal cual hemos reflejado en el fundamento anterior". 
tiene la Mesa y que consiste en la formulación de la correspondiente propuesta de adjudicación al órgano de contratación, lo que constituye un elemento esencial del procedimiento. Por tanto, puede concluirse que el procedimiento de licitación sería nulo de pleno derecho (artículo 47.1.e de la LPAC), en caso de que la intervención de la Mesa fuese preceptiva y esta no se constituyese ${ }^{45}$.

Al margen de las causas generales se establecen unas causas específicas del ámbito contractual, que contemplan diversas situaciones, tales como la falta de capacidad de obrar o de solvencia, estar incurso en prohibición de contratar, la carencia o insuficiencia de crédito y la falta de publicación del anuncio de licitación en el medio que corresponda, según el contrato. Causas muy diversas, pero con consecuencias de mucha gravedad.

Vamos a poner algunos ejemplos en los que se declara la nulidad ya sea a través del recurso administrativo especial o por sentencia en la vía contenciosa.

La Resolución 346/2013 del TACRC anula los pliegos del contrato de recogida de RSU (sumado a las prestaciones de limpieza viaria, mantenimiento de zonas verdes y alumbrado público) del Ayuntamiento de Guadalajara, al considerarlo un contrato de servicios (no un contrato de gestión de servicios públicos) suficiente para estimar el recurso. La calificación de un contrato como de concesión para la gestión de servicios públicos, cuando en el mismo no existe ningún riesgo operacional (y, que por esta razón se considera un contrato de servicios, según el derecho europeo), ha sido un evento en el que reiteradamente se ha derivado la declaración de nulidad, teniendo en cuenta además que la incorrecta calificación supone un régimen jurídico diferente.

Así la STS de 2 de octubre de $2000^{[46]}-\mathrm{y}$ las sentencias en ella citadasestablecía la falta de clasificación del contratista como causa de nulidad ya que "constituye un requisito imprescindible, constatándose la necesidad de acreditamiento de la aptitud técnica y financiera de los contratistas, en congruencia con la entidad de la obra y en previsión de asunción de compromisos desproporcionados a aquella capacidad técnica y financiera ${ }^{\prime \prime 4}$. La quiebra de

Tribunal Supremo, sentencia de la Sala Tercera, de lo Contencioso-Administrativo, sentencia de 3 de noviembre de 2004, recurso 2861/2002: precisa que la función básica de la Mesa consiste en la formulación de la correspondiente propuesta de adjudicación al órgano de contratación, lo que constituye un elemento esencial del procedimiento. Así, la formulación de esta propuesta por un órgano de distinta naturaleza y composición, y no competente para ello, como la Comisión Informativa de Hacienda.

Como ha afirmado el Tribunal Supremo en la Sentencia de 30 de enero de 2007, Sala de lo Contencioso-Administrativo, Sección 4, la falta de capacidad de obrar también supone una condición previa: "La contratación pública, al igual que la contratación privada, parte de la exigencia de la capacidad de obrar de las personas como condición previa. Pero, además, la validez del contrato exige unas específicas condiciones personales de los sujetos, fueren personas físicas o jurídicas, que pretendan contratar con la Administración a fin de no caer en nulidad de la adjudicación. Por ello lo sujetos han de reunir no solo condiciones de índole económica (solvencia económica y financiera), de índole técnica, 
la regla esencial, la confidencialidad, da lugar a la nulidad de actuaciones en aplicación de la doctrina del TACRC, sintetizada en su Resolución 225/2016:

la exigencia de respetar el principio de confidencialidad, y su especial vinculación con los principios de igualdad y libre concurrencia, resultando imposible efectuar una nueva valoración sujeta a juicios de valor, con posterioridad a la toma de conocimiento de las ofertas evaluables mediante fórmulas automáticas, de conformidad con lo establecido en el artículo 150.2 TRLCS.

Tratándose del principio de confidencialidad y su conexión con la igualdad y la seguridad jurídica, el Tribunal de Justicia de la Unión Europea, en sentencia de 30 de abril de 2014, Asunto T-637/2011, afirmó que se puede:

considerar garantizada la confidencialidad de las ofertas [por]que la comisión de apertura de las ofertas [se] halle en dos sobres sellados intactos. Esta norma contribuye de este modo a la seguridad jurídica, eliminando cualquier riesgo de apreciación arbitraria en la apertura de las ofertas, con un coste marginal desdeñable en medios económicos y técnicos, habida cuenta de todos los costes que conlleva la preparación de una oferta. Por consiguiente, la demandante no puede alegar fundadamente que tal obligación viola el principio de proporcionalidad.

Podemos resaltar además la necesidad de publicación del anuncio de licitación y la nulidad que se genera en caso de no respetar esta obligación. Un ejemplo de esto es la Resolución del Tribunal Català de Contratos del Sector Público $82 / 2019$, de 3 de abril de 2019, en la que ante la falta de publicidad comunitaria se establece la nulidad ${ }^{48}$.

También existen pronunciamientos de invalidez de un contrato por restricción de competencia, un ejemplo sería el Acuerdo 29/2011 del TACRC de Aragón, de 15 de diciembre, que consideró que un acuerdo marco era restrictivo de la competencia, concretamente el de la contratación centralizada de los servicios postales telegráficos para la Administración de la Comunidad

sino también moral, al no incurrir en ninguna de las prohibiciones de contratar consideradas en la norma".

48 Resoluciones 35/2018, 24/2018, 23/2018, 127/2016, 188/2014, 39/2014 y 49/2013 del Tribunal Català de Contractació $;$ resoluciones 418/2017, 237/2013, 220/2011, 203/2011 y 154/2011 del Tribunal Administrativo Central de Recursos Contractuales (TACRC); Sentencia del Tribunal de Justicia de la Unión Europea (TJUE) de 29 de octubre de 2009, C-536/07, Comisión/Alemania; También la Resolución del TACRC n. ${ }^{\circ}$ 366/2016, de 13 de mayo establece la nulidad de una adjudicación por considerarla arbitraria: "En conclusión y de todo lo hasta aquí razonado, ha de anularse la adjudicación efectuada a Acideka, en la medida en que la valoración técnica, además de inmotivada, resulta claramente arbitraria en comparación con los pliegos y ofertas presentadas con anterioridad." 
Autónoma de Aragón, sus organismos autónomos y demás entes públicos autonómicos y locales adheridos ${ }^{49}$.

El derecho europeo (directivas 89/665 y 92/13, modificadas por la Directiva 2007/66/CE del Parlamento Europeo y del Consejo de 11 de diciembre de 2007), al imponer a los diferentes Estados un sistema propio de control en los procedimientos de adjudicación de contratos públicos ha supuesto en España una revolución tanto en la interposición como en las resoluciones de nulidad por parte de los tribunales administrativos. Solo por resaltar el Tribunal Català de Contractes del Sector Público emitió más de 400 resoluciones en las que estimaba o no la nulidad de las materias sobre las que tiene competencia.

b. Anulabilidad: La anulabilidad supone una infracción del ordenamiento, considerada por el propio legislador, pero de un grado inferior y con consecuencias jurídicas menores a las previstas en los supuestos de nulidad.

Las causas de anulabilidad de derecho administrativo están reguladas en el artículo 40 de la LCSP y son aquellas otras infracciones previstas en el ordenamiento jurídico. Se trata en particular de las reglas contenidas en esa misma ley, de conformidad con lo establecido en el artículo 48 de la Ley 39/2015, del Procedimiento Administrativo Común de las Administraciones Públicas. De acuerdo con lo dispuesto por el artículo 40 de la LCSP, se incluyen entre las causas de anulabilidad a las que se refiere el párrafo anterior, las siguientes:

a) El incumplimiento de las circunstancias y requisitos exigidos para la modificación de los contratos en los artículos 204 y 205.

b) Todas aquellas disposiciones, resoluciones, cláusulas o actos emanados de cualquier poder adjudicador que otorguen, de forma directa o indirecta, ventajas a las empresas que hayan contratado previamente con cualquier Administración.

c) Los encargos que acuerden los poderes adjudicadores para la ejecución directa de prestaciones a través de medios propios, cuando no observen alguno de los requisitos establecidos en los apartados 2, 3 y 4 del artículo 32, relativos a la condición de medio propio.

Aquí debemos destacar también la existencia de unas causas generales y unas causas específicas en materia contractual de anulabilidad. Las causas generales

49 Establece la Directiva 2014/24/UE en el considerando 59, que deben supervisarse cuidadosamente para evitar una excesiva concentración de poder adquisitivo y la colusión, y preservar la transparencia y la competencia, así como las posibilidades de acceso al mercado de las pymes. El Tribunal declaró la invalidez del citado acuerdo marco considerando que, al haberse celebrado con un único proveedor y al tener un ámbito subjetivo excesivamente amplio -ya que engloba la casi totalidad de las entidades públicas de Aragón-, la consecuencia era el cierre del mercado público de los servicios postales en Aragón durante un plazo de cuatro años 
también se encuentran en la LPAC, en su artículo 48, cuando establece que son anulables los actos de la Administración que incurran en cualquier infracción del ordenamiento jurídico, incluso la desviación de poder. Aunque luego se establece que el defecto de forma solo determinará la anulabilidad cuando el acto carezca de los requisitos formales indispensables para alcanzar su fin o dé lugar a la indefensión de los interesados. Además, se dispone que la realización de actuaciones administrativas fuera del tiempo establecido para ellas solo implica la anulabilidad del acto cuando así lo imponga la naturaleza del término o plazo.

Los diferentes vicios de anulabilidad suponen entender que los efectos de su declaración son ex nunc y se da la posible convalidación de las infracciones del ordenamiento ${ }^{50}$. En la mayoría de los supuestos de anulabilidad no llega casi el control administrativo, ni el de los tribunales administrativos ni el de la jurisdicción contenciosa administrativa, y lo que sucede es que en la mayoría de los casos es que se produce una convalidación del vicio de anulabilidad existente en el ámbito contractual ${ }^{51}$. Donde más se producen los casos de anulabilidad es en los temas de carácter formal, siempre que no se puedan incluir en ningún supuesto del artículo 39 de la LCSP.

Como ejemplos de anulabilidad podemos destacar la desviación de poder ${ }^{52}$, también, como ya hemos dicho, como realización de actuaciones administrativas con defectos de forma, entre ellos realizar una actuación fuera del tiempo establecido para ella, siempre que este plazo por su naturaleza tenga trascendencia $^{53}$. En la Resolución 389/2017 del TACRC se señala que al no contener la normativa de contratos previsión alguna que permita concluir la invalidez del acuerdo de adjudicación finalmente adoptado, en aquellos casos en que este ha sido dictado más allá del plazo legalmente previsto, resulta de aplicación la regla general contenida en la Ley de Procedimiento Administrativo 39/2015. Esta disposición reitera la regla general según la cual la realización de actuaciones administrativas fuera del tiempo establecido para ellas solo implicará la anulabilidad del acto cuando así lo imponga la naturaleza del término o plazo ${ }^{54}$.

En la STS M-11415/2017 de 3 de noviembre de 2017 realiza una aclaración sobre la previsión normativa de la infracción no subsanable, de manera que:

50 Teresa Moreno Marroig, "La ejecución del contrato tras la entrada en vigor de la Ley 9/2017", Revista Española de Control Externo, vol. xX, n. ${ }^{\circ} 60,2018$, pp. 161 y ss.

51 José Antonio Tardío Pato, "Los efectos ex tunc de la anulabilidad", óp. cit., pp. 6 y ss

52 Tribunal Administrativo Central de Recursos Contractuales, resolución n. ${ }^{\circ}$ 366/2016 de 13 de mayo de 2016, Recurso n. ${ }^{\circ}$ 279/2016, incluidas la desviación de poder Tribunal Supremo, sentencia de 18 de marzo de 2011, Casación n. ${ }^{\circ}$ 1643/2007, Tribunal Supremo, sentencia de 18 de marzo de 2011, Casación n. ${ }^{\circ}$ 1643/2007: Anulabilidad por desviación de poder.

53 Tribunal Supremo, sentencia de 5 de julio de 2016, Casación n. ${ }^{\circ}$ 1515/2015: Anulabilidad por defectos de forma.

54 Tribunal Administrativo Central de Recursos Contractuales, Resolución 389 de 28 de abril de 2007, Recurso n. ${ }^{\circ}$ 286/2017 C.A. Galicia 36/2017 
Esta Sala discrepa de que la infracción no subsanable de las normas de preparación del contrato a la que alude el artículo 155.4 del TRLCSP, equivalga a un vicio o causa de nulidad de pleno derecho, en primer lugar porque la literalidad del precepto en ningún momento hace referencia a un supuesto de nulidad de pleno derecho, y en segundo término porque la mayor parte de las infracciones de las normas que, no constituyendo nulidad de pleno derecho sino supuestos de anulabilidad, no por ello son convalidarles o carecen de eficacia invalidante, como resulta de los artículos 63 y 67 de la LPAC. Avala la postura anterior la Resolución número 644/2017 de fecha 14 de julio de 2017, del Tribunal Administrativo Central de Recursos Contractuales, que argumenta detalladamente las razones por las que no procede reducir la expresión controvertida "infracción no subsanable de las normas de preparación del contrato", exclusivamente a supuestos de nulidad de pleno derecho, cuya doctrina esta Sala comparte íntegramente.

De acuerdo con la sentencia, lo más trascendental, al margen de los efectos, es sobre todo la diferencia entre la subsanabilidad de la anulabilidad y la no subsanabilidad de la nulidad.

\section{EFECTOS DE LA DECLARACIÓN DE NULIDAD Y DE ANULABILIDAD}

De especial trascendencia en este estudio es el de las consecuencias jurídicas y también de las consecuencias reales que tienen la declaración de nulidad o de anulabilidad, ya sea por parte de la propia Administración o de los tribunales administrativos de recursos especiales, o bien sea por la jurisdicción que corresponda. En todo caso, nos vamos a centrar fundamentalmente en los efectos de la nulidad y la anulabilidad por causas propias del derecho administrativo.

En todo caso, los efectos de la nulidad civil se aplican desde el artículo 1303 hasta el 1308 del Código Civil. La Sala Civil del TS en la STS de 26 de julio de $2000^{[55]}$ explica que la declaración de nulidad debe suponer volver a la situa-

55 Tribunal Supremo, sentencia de la Sala 1. ${ }^{a}$ Civil, de 26 de julio de 2000, Casación n. ${ }^{\circ}$ 2925/1995. "El artículo 1303 del CC establece que, declarada la nulidad de una obligación, los contratantes deben restituirse recíprocamente las cosas que hubiesen sido materia del contrato, con sus frutos, y el precio con los intereses. Y la Jurisprudencia viene declarando que el precepto tiene como finalidad conseguir que las partes afectadas vuelvan a tener la situación personal y patrimonial anterior al efecto invalidador (sentencia 30 diciembre 1996), de tal modo que cuando el contrato hubiere sido ejecutado en todo o en parte procede la reposición de las cosas al estado que tenían al tiempo de su celebración (SS. 29 octubre 1956, 22 septiembre 1989 y 28 septiembre 1996). Por lo tanto, debe darse lugar a la reposición de las cosas y el reintegro del precio (S. 28 septiembre 1996), devolver el dinero percibido con los intereses (S. 23 junio 1997). El precepto anterior puede resultar insuficiente para resolver todos los problemas con traducción económica derivados de la nulidad contractual por lo que puede ser preciso acudir a la aplicación de otras normas (como la propia parte recurrente implícitamente reconoce), de carácter complementario, 
ción personal y patrimonial anterior al contrato, dando "lugar a la reposición de las cosas y el reintegro del precio (devolver el dinero percibido con los intereses)". Además, puede tenerse que acudir a "los preceptos generales en materia de incumplimiento de obligaciones (artículos 1101 y ss.) Y los relativos a la liquidación del estado posesorio (artículos 452 y ss.), sin perjuicio de tomar en consideración también el principio general de derecho que veda el enriquecimiento injusto" 56 .

De especial importancia son los efectos reales que tiene la declaración de nulidad y anulabilidad de los diferentes actos que forman parte del procedimiento contractual. Aunque para ello habrá que previamente haberse declarado la invalidez. En el Informe 18/2013 de 25 de septiembre de la Junta Consultiva de Contratación Administrativa de la Comunidad Autónoma de Aragón, en un proceso de revisión de oficio, se explica cómo el contrato nulo no tiene efectos:

El principio de conservación de los actos determina que la nulidad deba declararse para que el acto deje de producir efectos, de tal forma que será necesario declarar formalmente la invalidez del acto para privarle así de su eficacia. [...] En este punto, hay que matizar que, de no existir acto expreso o presunto contrario al ordenamiento jurídico, sino una mera situación fáctica que se ha venido sucediendo en el tiempo y que se considera irregular, debería a la mayor brevedad ponerse fin, sin más efectos que la correspondiente retribución por los servicios prestados en aplicación de la teoría del enriquecimiento injusto. Si la modificación se ha perfeccionado, es firme en vía administrativa y, por lo tanto, despliega sus efectos,

o supletorio, o de observancia analógica, tales como los preceptos generales en materia de incumplimiento de obligaciones (artículos 1101 y ss.) y los relativos a la liquidación del estado posesorio (artículos 452 y ss.), sin perjuicio de tomar en consideración también el principio general de derecho que veda el enriquecimiento injusto".

56 Tribunal Supremo, sentencia de la Sala Tercera de lo Contencioso Administrativo de 11 de enero de 2013, recurso n. ${ }^{\circ} 462 / 2013$; Del mismo modo, el Tribunal Supremo en sentencia de 11 de enero de 2013 sostiene en relación con los efectos de la nulidad y la anulabilidad que: "Conviene recordar que las diferencias entre nulidad y anulabilidad en el ámbito civil no tienen porqué trasladarse sin más al administrativo. En primer lugar, en el orden civil la regla general es la nulidad, mientras que en el administrativo es la excepción, reservada a los casos más graves del ordenamiento jurídico (artículos 62 y 63 de la ley 30/1992, antes citada). Que, aunque no exista plazo para reclamar en ambos ámbitos ordinamentales, este puede ser moderado en vía administrativa, en virtud del artículo 106 de la última norma citada. Que al contrario de lo ocurre en la vía civil, en cuanto a la retroactividad, que no se produce en la anulación, sino desde el ejercicio de la acción, en la jurisdicción contenciosoadministrativa, el reconocimiento de la situación jurídica individualizada (artículo 31.2 de la Ley Reguladora de la Jurisdicción Contencioso-Administrativa), hace que también en la anulación los efectos se retrotraigan al momento anterior a la resolución impugnada. En consecuencia, aquí se ha declarado la nulidad de un contrato administrativo por la aplicación del artículo 62.1 de la Ley 30/1992, y los efectos jurídicos de dicha declaración de nulidad han de extraerse, no de la legislación civil, sino de la Administrativos". 
deberá ser objeto de un procedimiento de revisión de oficio o, de ser aplicable, de nulidad especial en materia contractual.

En primer lugar, hace falta detenerse en el artículo 42 de la LCSP dedicado a los efectos de la declaración de nulidad y de anulabilidad. En este artículo se distingue entre la nulidad de los actos preparatorios del contrato de los que no lo son. Así las cosas, la declaración de nulidad de los actos preparatorios del contrato o de la adjudicación, cuando sea firme, "llevará en todo caso consigo la del mismo contrato, que entrará en fase de liquidación, debiendo restituirse las partes recíprocamente las cosas que hubiesen recibido en virtud del mismo y si esto no fuese posible se devolverá su valor". Además, añade el artículo 42.1 que la parte que resulte culpable deberá indemnizar a la contraria de los daños y perjuicios que haya sufrido.

En la STS Civil, de 10 de julio de $1998^{[57]}$ se establece que:

si, en principio y por regla general, los efectos de la resolución contractual se producen ex tunc, colocando a los intervinientes en la misma situación en que se hallarían si el contrato no se hubiese celebrado, lo que lleva consigo la obligación de restituir cada parte lo que haya recibido de la otra por razón del vínculo obligacional, sin perjuicio del derecho de terceros adquirientes de buena fe, esa eficacia retroactiva no puede aplicarse respecto a relaciones duraderas que, en todo o en parte, han sido consumadas, cual sucede en contratos como los de arrendamiento, de agencia o de comisión mercantil, en que la resolución del vínculo contractual opera ex nunc, produciéndose, por tanto, únicamente efectos liquidatarios de la situación existente al tiempo de la resolución contractual.

En cambio, la nulidad de los actos que no sean preparatorios "solo afectará a estos y sus consecuencias". Se establece una excepción a los efectos de la nulidad y anulabilidad y es que "Si la declaración administrativa de nulidad de un contrato produjese un grave trastorno al servicio público, podrá disponerse en el mismo acuerdo la continuación de los efectos de aquel y bajo sus mismas cláusulas, hasta que se adopten las medidas urgentes para evitar el perjuicio". Fijémonos que en el contenido del artículo no se hace distinción entre los grados de invalidez en los que se encuentra el acto que es objeto de la declaración de nulidad, pero en cambio sí diferencia el tipo de acto inválido. "Si se trata de un acto precontractual, la invalidez se contagia al contrato que se haya podido celebrar con posterioridad. Si, por el contrario, el acto no es preparatorio, de lo que hay que deducir que el legislador se refiere a actos en la fase de ejecución del contrato, entonces, la invalidez solo afecta a esos actos

57 Tribunal Supremo, sentencia de la Sala Civil, Repositorio Oficial de Jurisprudencia: STS 4648/1998. 
y sus consecuencias ${ }^{\prime \prime 5}$. Si el contrato entra en liquidación, tal como propone la ley, en caso de que se declare la nulidad de los actos preparatorios del contrato o de la adjudicación, se genera la consecuencia de restituir a las partes y sino el valor del mismo. Estos efectos a menudo son de imposible ejecución ya que lo que sucede es que el contrato ya se ha realizado en parte o incluso a veces totalmente. En estos casos lo que sucede es que el contratista debe recibir la contraprestación correspondiente por los trabajos realizados.

Esta situación de liquidación, prevista en la LCSP, está pensada para un evento como el que teníamos anteriormente, en el que los posibles controles administrativos y jurisdiccionales era tan lentos que el contrato, cuando se declaraba nulo, estaba ya en fase de ejecución o ya había finalizado. En la regulación actual, como ya hemos dicho antes, la existencia del recurso especial en materia de contratos hace innecesarios llegar a estos efectos tan radicales de entrar en liquidación, ante la nulidad de los actos preparatorios o de adjudicación del contrato. La propia LCSP establece en los artículos 57 y 58 las consecuencias que puede tener un acto inválido: anulación de las decisiones ilegales, retroacción de actuaciones y, en su caso, indemnización por los daños y perjuicios ocasionados al recurrente. Por el contrario, el tribunal administrativo no podrá a través del recurso especial adjudicar el contrato directamente ${ }^{59}$.

Las opciones tan radicales de la ley en caso de invalidez del contrato tienen límites, que conllevan que un acto inválido pueda ser eficaz. Hay que tener en cuenta la previsión del artículo 110 de la LPAC cuando establece los límites a la revisión, al establecer que "no podrá revisarse un acto cuando por prescripción de acciones, por el transcurso del tiempo o por otras circunstancias, el resultado sería contrario a la equidad, la buena fe, el derecho de los particulares o a las leyes". Ni qué decir sobre el tema de la declaración de lesividad, en el que existen unos límites propios: el tiempo (cuatro años) y la necesidad de declaración de la lesividad por parte de órgano competente.

Además, como ya hemos visto, el propio artículo 42, en su apartado tercero, admite el mantenimiento de los efectos de un contrato nulo cuando se pudiera producir un grave trastorno al servicio.

En consonancia con lo anterior, uno de los temas más importantes que se debe tratar es el de la eficacia retroactiva -o no- de los actos nulos, y la diferencia que existe con los anulables. Es decir, no nos sirve en materia de contratación, al igual que en otros supuestos, los efectos ex tunc y ex nunc de la invalidez de los actos.

Silvia Diez Sastre, "Los efectos de la invalidez en la Ley de Contratos del Sector Público", Revista Documentación Administrativa. Nueva Época, n. ${ }^{\circ}$ 5, 2018. Disponible en: https://revistasonline.inap.es/index.php/DA/article/view/10608/11405 [consultado 10 de agosto de 2020].

Esta previsión existía en artículo 47.2 in fine TRLCSP. 
Los efectos principales de la anulación de un acto inválido son ${ }^{60}$ :

\subsection{LIQUIDACIÓN DEL CONTRATO}

La invalidez que afecta a los actos de preparación o adjudicación de los contratos supone que el contrato celebrado con posterioridad entra en liquidación y la restitución de las cosas que las partes hubieran intercambiado, en caso de que no sea posible la restitución, se devolverán su valor (artículo 42.1 de la LCSP). Lo normal será la imposibilidad de restitución y por tanto la devolución del valor de las cosas intercambiadas.

Las obligaciones de restitución que surgen no son fruto del contrato, ya que este ha sido anulado y por tanto no existen. Es por esto que la LCSP impone en todo caso devolver el valor de lo que se ha dado de una parte a la otra ${ }^{61}$. En la práctica para esta compensación se acude a la teoría del enriquecimiento injusto $^{62}$.

60 Silvia Diez Sastre, "Los efectos de la invalidez en la Ley de Contratos del Sector Público", óp. cit., p. 77.

61 Vicenç Aguado I Cudolà, "Efectos de la invalidez y prórroga de los contratos públicos", óp. cit., p. 223 a 272.

62 En una resolución reciente el Consejo Consultivo de Andalucía 0384/2020 de 8 de julio del 2020 establece que "En cuanto a los efectos de la declaración de nulidad, debe partirse del 42.1 de la LCSP, conforme al cual la declaración de nulidad de los actos preparatorios del contrato o de la adjudicación, cuando sea firme, llevará en todo caso consigo la del mismo contrato, que entrará en fase de liquidación, debiendo restituirse las partes recíprocamente las cosas que hubieran recibido en virtud del mismo y si esto no fuese posible se devolverá su valor. La parte que resulte culpable deberá indemnizar a la contraria de los daños y perjuicios que haya sufrido. En relación con esto último, este Consejo Consultivo ha venido declarando que, en principio, la restitución solo puede comprender el valor de la prestación realizada, lo que incluye sus costes efectivos, pero no los demás componentes retributivos propios de un contrato válidamente celebrado, dado que, al ser el contrato nulo, no produce efectos económicos propios del contrato eficaz, por lo que la obligación de devolver no deriva, en este caso, del contrato, sino de la regla legal (en este caso el art. 42.1 de la LCSP) que determina la extensión de la restitución únicamente al valor de la prestación, incluyendo, por consiguiente, todos los costes (y tan sólo los mismos) soportados por quien la efectuó. Ya en su primera etapa expuso este Consejo Consultivo (dictamen 2/1995), que 'no solo la Administración debe recibir el reproche por su irregular proceder, sino que también cabe reputar a los contratistas como cocausantes de la nulidad'. Así, este Órgano Consultivo ha señalado en reiteradas ocasiones que el contratista que consiente una irregular actuación administrativa, prestando por su parte unos servicios sin la necesaria cobertura jurídica sin oposición alguna, se constituye en copartícipe de los vicios de que el contrato pueda adolecer, dando lugar a que recaigan sobre él mismo las consecuencias negativas de tales vicios. En esta dirección el Consejo ha insistido en que resulta improbable que quien contrata con la Administración desconozca, por mínima que sea su diligencia, que no puede producirse una contratación prescindiendo de todo procedimiento. Solo se ha exceptuado la aplicación de dicha doctrina cuando se aprecian circunstancias que justifican el abono integro de la prestación, tal y como fue convenida, sobre todo cuando no 
Con respecto a la devolución del valor en el Dictamen de la Comissió Jurídica Assessora de la Generalitat de Catalunya 244/2016, de 15 de septiembre, en el que se planteaba una revisión de oficio a instancia del Ayuntamiento de Ascó para declarar la nulidad del contrato del servicio de grúa adjudicado a la empresa Auto Sport Flix, SL donde se señala: "Para llevar a cabo esta liquidación, y considerando que no es posible restituir in natura las prestaciones percibidas, se ha de retornar su valor, de acuerdo con lo previsto en el artículo 35 del TLRCSP. Así, en aplicación de este precepto, la adjudicataria ha de retornar, en relación con los períodos comprendidos por la prórroga y por la contratación verbal que han sido declarados nulos de pleno derecho las cantidades percibidas y el Ayuntamiento habrá de proceder al pago de los servicios prestados efectivamente."

En referencia al enriquecimiento injusto se trata de que el contratante haya realizado efectivamente toda o parte de la prestación encargada y no haya obtenido a cambio la contraprestación acordada. Desde la jurisprudencia civil se ha creado la figura del enriquecimiento injusto (como principio general y como acción) y se aplica también en el orden contencioso-administrativo, aunque en este caso hay que tener en cuenta que esta teoría tiene algunas diferencias.

Para que se dé el enriquecimiento es necesario, por un lado, que haya un enriquecimiento o un aumento del patrimonio de una de las partes, en nuestro caso del poder adjudicador, y que esta ventaja debe producirse con efectos definitivos. Por otro lado, se debe producir un empobrecimiento de la otra parte, que no debe ser causado directamente en el comportamiento de quien lo sufre. También y finalmente entre una situación y otra debe haber una relación causal. La acción para pedir el enriquecimiento injusto (actio in rem verso), debe ejercitarse en un plazo de cuatro años y si no prescribe. También se puede ejercer reconocimiento extrajudicial de crédito frente a la Administración.

puede calificarse al contratista como participe de la nulidad. [...] Hay que tener en cuenta, además y como resulta de lo expuesto, que la empresa que ha prestado los servicios cuyo encargo se pretende declarar nulo es la empresa que se encontraba prestando los servicios en virtud de un contrato cuya validez no se ha puesto en tela de juicio y que ha sido, a la vez, la nueva adjudicataria del servicio. Hacerla culpable de ello supondría haberle exigido que se negara a prestar el servicio durante ese mes y ocho días, de modo que no se hubiera prestado el servicio con la ineludible afectación al interés público que resulta del expediente. La Administración podría habérselo encargado también ilegalmente a otra empresa, pero entonces también ésta sería culpable de la nulidad de su contratación pues tales servicios se habrían prestado sin cobertura contractual adecuada. En definitiva, negando el beneficio industrial, la Administración, a la que únicamente cabe reprochar la situación, obtendría un beneficio de dudosa legitimidad y la decisión podría incluso calificarse como manifiestamente injusta con las consecuencias que ello podría acarrear. En definitiva, con carácter excepcional procede el abono del precio íntegro de los servicios prestados y debidos sin descontar el beneficio industrial, como se contempla en la propuesta de resolución". 
En la STS de Castilla-La Mancha de 17 de febrero de 2001 se establece cómo la doctrina del Tribunal Supremo viene entendiendo el enriquecimiento injusto. "en base en el principio de prohibición del enriquecimiento sin causa, que, aunque se anule un contrato por defectos legales del mismo, si resulta que la prestación ha sido efectuada por el contratista, no puede pretenderse después no efectuar el pago de la contraprestación dineraria correspondiente ni la devolución de lo ya pagado; todo ello salvo casos de mala fe por parte del contratista". En el Dictamen 140/2004 del Consejo Jurídico de la Región de Murcia se añade que "tal obligación de abono de los servicios no tiene por título el contrato, que no existe y es nulo de pleno derecho, sino evitar el enriquecimiento injusto de la Administración que ha recibido tales servicios (STS, Sala 3. ${ }^{\text {a }}$, sec. 7. ${ }^{\text {a }}, 30$ de septiembre de 1999)".

\subsection{Restablecimiento de La Legalidad}

El restablecimiento de la legalidad supone que una vez declarada la nulidad se retrotraigan las cosas al momento en que se cometió la infracción para volver a la situación de legalidad. A veces este restablecimiento aludido no es posible, bien sea porque el contrato está finalizado o porque lo ejecutado es difícil o imposible de devolver. Asimismo, la restitución de la legalidad puede suponer que se le imponga a la Administración la realización de una conducta concreta.

También en algunos casos, cuando no se pueden retrotraer las actuaciones, la invalidez puede suponer la cancelación del contrato. Se puede producir la cancelación por decisión de la Administración, antes de la formalización del contrato, cuando se han producido infracciones insubsanables en la preparación del contrato o de las normas reguladoras del procedimiento, la Administración puede desistir sin que ello impida que pueda volver a abrir una nueva licitación con el mismo objeto con posterioridad (artículo 152.2).

A veces, y tal como prevé la propia LCSP en el artículo 42.3, no se podrá restablecer la legalidad y se deberá garantizar la continuidad del servicio, incluso más allá de la declaración de invalidez. Como vemos, en la legislación prima el interés general por encima de la legalidad ${ }^{63}$.

\subsection{El RESARCimiento de DAÑOS Y PERJUicios}

El resarcimiento de los daños y perjuicios ocasionados como consecuencia de la invalidez del contrato supone un deber indemnizatorio, supeditado, tal como dice el artículo 42.1, a que la parte que resulte culpable deba indemnizar a la contraria de los daños y perjuicios que haya sufrido. Existen diferentes

63 Artículo 43 del Reglamento de Contratación de las Corporaciones Locales y, en la actualidad, del derecho europeo (artículo 2 quinquies Directiva 2007/66/CE). 
supuestos en los que se puede dar este resarcimiento, pero en todo caso habrá que demostrarse, siempre que se invalide la adjudicación de un contrato, que a quien se resarce hubiera resultado siendo el adjudicatario, la culpabilidad del causante y la relación de causalidad entre su actuación y el daño. Al margen de esta responsabilidad contractual es posible plantear la existencia de la responsabilidad patrimonial fruto de la invalidez, que debe cumplir con los requisitos propios de la responsabilidad patrimonial de la Administración.

- En lo que respecta a los conceptos indemnizables, en el caso de pérdida del contrato existe una opinión unánime, que se muestra favorable a indemnizar el beneficio industrial ${ }^{64}$ perdido a quien debería haber sido adjudicatario.

- De los daños causados al contratista se deben

reparar los gastos en que incurrió en la creencia de que seguiría ejecutando el contrato en el futuro y que devienen inútiles cuando debe liquidarse el contrato y adjudicarse a otro. Se trata de un daño a la confianza creada por la Administración en que podría ejecutarse el contrato conforme a se pactó en su día. Por esa razón, el concepto indemnizable son los daños a la confianza, el interés negativo ${ }^{65}$.

- Vamos a ver diferentes supuestos en los que se determinan, por los tribunales o por los tribunales administrativos, los efectos de la anulación. Al respecto, el Tribunal Supremo, en sentencia de 12 de febrero el 2020 $0^{[66]}$, rechaza la pretensión de adjudicar la concesión a los recurrentes, tras la declaración de anulación de la adjudicación:

La doctrina reiterada del Tribunal Constitucional, así SSTC 97/1993, de 22 de marzo, FJ2; 353/1993, de 25 de noviembre, FJ3; 34/1995, de 6 de febrero, FJ3; 73/1998, de 31 de marzo, FJ5; 86/2004, de 19 de mayo, FJ3; y 17/2009, de 29 de enero, FJ5, entre otras, establece que "lo que no pueden hacer los Tribunales de Justicia es sustituir en la valoraciones técnicas a los órganos administrativos calificadores". Y en la STC 219/2004, de 29 de noviembre, FJ6, se añade a la frase antes transcrita: "está vedado, por tanto, la nueva valoración de un ejercicio de un proceso selectivo, salvo circunstancias excepcionales". Y, en cuanto a la jurisprudencia de esta Sala, las sentencias de 14 de julio de 2000, rec. 258/1997; de 15 de enero de 2008 y de 27 de mayo de 2009, entre otras, declaran: "La discrecionalidad técnica reduce las posibilidades del control de dicha actividad evaluadora, que prácticamente estarán constituidas por estos dos básicos supuestos: el de la inobservancia de los elementos reglados -cuando estos existan-, y el del error ostensible o manifiesto; $\mathrm{y}$, consiguientemente, deja fuera de ese limitado control posible a aquellas pretensiones de los interesados que solo postulen una evaluación alternativa a la del

64 Se cifra en el 6\% del precio de adjudicación del contrato (artículo 264.4 de la LCSP).

65 Silvia Diez Sastre, "Los efectos de la invalidez en los procedimientos de adjudicación de contratos públicos", óp. cit., p. 81.

66 Tribunal Supremo, sentencia del 12 de febrero de 2020, Casación n. ${ }^{\circ}$ 3226/2016. 
órgano calificador, pero moviéndose también dentro de ese aceptado espacio de libre apreciación, y no estén sustentadas con un posible error manifiesto.

El Informe 9/2014 de la Junta Superior de Contractació Administrativa de la Generalitat Valenciana, respecto los efectos de la contratación verbal, determina que "Si se contrataron obras en las condiciones expresadas [...] pero con conocimiento y consentimiento de la Administración, y en su propio beneficio, los efectos de la declaración de nulidad se encuentran establecidos en el artículo 35.1 del TRLCSP, a tenor del cual debe practicarse la liquidación del contrato de las obras efectuadas y restituirse el enriquecimiento obtenido mediante el abono de su valor a la empresa contratista que las ejecutó, previo reconocimiento extrajudicial de créditos si fuese necesario".

En cambio, en otros casos el respeto a la legalidad supone solo retrotraer las cosas al momento en que se produjo la infracción ${ }^{67}$. Dispone la Resolución n. ${ }^{\circ}$ 190/2014 del TACRC ${ }^{68}$ la necesidad de volver las cosas a la situación anterior:

Estimar el recurso interpuesto por D. G. R. M., en nombre y representación de Limpiezas, Ajardinamientos y Servicios Seralia S. A., contra la resolución del Gerente de Gestión Integrada de Lugo, Cervo y Monforte de Lemos de 23 de diciembre de 2013 por la que se le excluye del procedimiento de licitación del contrato de "Servicio de limpieza del Hospital da Costa de Burela (Lugo)" (Exp. AB-EIL2-13-001), licitada por el Servicio Gallego de Salud (Sergas), declarando nulo el acto recurrido y el precedente de la mesa de contratación de 18 de diciembre de 2013 en cuanto propone la exclusión de la recurrente, y ordenando reponer las actuaciones al momento de la apertura del sobre A de la documentación administrativa, sin perjuicio de conservar aquellas partes de dicho acto, así como los actos y trámites posteriores, cuyo contenido se hubiera mantenido igual de no haberse cometido la infracción.

67 La Resolución n. ${ }^{\circ}$ 180/2020 del Tribunal Administrativo Central de Recursos Contractuales, de 6 de febrero de 2020, C. A. de Castilla-La Mancha señala: "Pues bien, sobre esa pretendida nulidad o anulabilidad de los pliegos, lo cierto es que, aun estimando las demás pretensiones de la recurrente por los motivos expuestos en los dos fundamentos anteriores, ello no conlleva la nulidad del procedimiento de licitación en su conjunto, sino únicamente la necesidad de retrotraer el procedimiento al momento anterior a la aprobación de los pliegos rectores del mismo, con el fin de redactarlos teniendo en cuenta el pronunciamiento de este Tribunal. Y ello porque, de conformidad con los artículos 49 y 51 de la Ley 39/2015, de 1 de octubre, la nulidad parcial del pliego no implica la de los actos del procedimiento independientes del anulado, ni la del resto del pliego no anulado, conservándose por tanto los actos, parte de los mismos, y trámites cuyo contenido se hubiera mantenido igual de no haberse cometido la infracción".

68 Tribunal Administrativo Central de Recursos Contractuales, Resolución n. ${ }^{\circ}$ 190/2014 Recurso n. ${ }^{\circ}$ 084/2014 C.A. Galicia 009/2014. 


\section{CONCLUSIONES}

Las diferentes directivas europeas no abordan de forma directa los vicios de los contratos y, por tanto, las consecuencias de su infracción, pero sí dan por sentado que las previsiones normativas que contienen deben ser respetadas en la legislación de cada Estado miembro y que su infracción puede suponer la invalidez del procedimiento contractual o de su propia adjudicación. De esta manera, la Directiva 2007/66/CE de recursos, tiene como objetivo velar por el cumplimiento de la legislación comunitaria, en particular, en la etapa en la que aún podrían corregirse las infracciones. La introducción en el derecho español de un recurso especial para la contratación ha cambiado el panorama de la impugnación en esta materia. Del mismo modo, el régimen de invalidez contractual establecido en la LCSP afecta a todos los contratos celebrados por los poderes adjudicadores. En este sentido, se establece un régimen de nulidad y anulabilidad, en el que estas consecuencias pueden ser provocadas por causas derivadas de la infracción del ordenamiento civil y administrativo. Ahora bien, la investigación muestra que el régimen jurídico y las consecuencias de la invalidez no son iguales si las causas son del derecho civil o del derecho administrativo.

Tratándose de la nulidad absoluta, como consecuencia de una infracción grave al ordenamiento, se tiene que esta es imprescriptible, insubsanable e indisponible por el particular. En contraste, la anulabilidad supone un grado inferior y con consecuencias jurídicas menores a las previstas en los supuestos de nulidad. Por ende, las causas de nulidad de derecho administrativo están reguladas en el artículo 39 y los de la anulabilidad en el artículo 40 de la LCSP. El texto normativo dispone que la declaración de nulidad de los actos preparatorios del contrato o de la adjudicación, cuando sea firme, "llevará en todo caso consigo la del mismo contrato, que entrará en fase de liquidación, debiendo restituirse las partes recíprocamente las cosas que hubiesen recibido en virtud del mismo y si esto no fuese posible se devolverá su valor". En cambio, la nulidad de los actos que no sean preparatorios "solo afectará a estos y sus consecuencias".

En consonancia con lo anterior, el artículo 42.1 establece que la parte que resulte culpable deberá indemnizar a la contraria de los daños y perjuicios que haya sufrido. Además, si el contrato entra en liquidación, tal como propone la ley, en caso de declaración de nulidad firme de los actos preparatorios del contrato o de la adjudicación, se desprende la obligación de restituir a las partes y sino el valor del mismo. Estos efectos a menudo son de imposible ejecución ya que lo que sucede es que el contrato ya se ha realizado en parte o incluso a veces totalmente. En estos casos, lo que ocurre es que el contratista debe recibir la contraprestación correspondiente por los trabajos realizados. Es menester resaltar la excepción que existe en este artículo en cuanto a los efectos de la nulidad y anulabilidad, la cual consiste en que si la declaración administrativa 
de nulidad de un contrato produjese un grave trastorno al servicio público, será posible disponer en el mismo acuerdo la continuación de los efectos de aquel, hasta que se adopten las medidas urgentes para evitar el perjuicio.

\section{BIBLIOGRAFÍA}

Aguado i Cudolà, VicEnç. "Efectos de la invalidez y prórroga de los contratos públicos". En Fernando López Ramón y Francisco Villar Rojas (coords.), El alcance de la invalidez de la actuación administrativa. Madrid: INAP, 2017.

Alonso, Carmen. Ley de contratos del sector público: Ámbito de aplicación. Modalidades contractuales y régimen de invalidez de los procedimientos de contratación. Barcelona: Fundación Democracia y Gobierno Local, 2009.

Aymerich CANo, Carlos. Un problema pendiente: la anulación de los contratos administrativos afectados por actos de corrupción. Cizur Menor: Thomson - Reuters, Aranzadi, 2015.

Beladiez Rojo, Margarita. Validez y eficacia de los actos administrativos. Madrid: Marcial Pons, 1994.

Campos Acuña, María Concepción. La nueva contratación pública en el ámbito local. Madrid: Editorial El Consultor de los Ayuntamientos, 2018.

Carrascosa lópez, Valentín, Asunción Pozo Arranz y Eduardo Rodríguez de CASTRO. "El consentimiento y sus vicios en los contratos perfeccionados a través de medios Electrónicos". Informática y Derecho. Revista Iberoamericana de Derecho Informático, n. ${ }^{\circ} 12-15,1996$.

Diez Sastre, Silvia. "Los efectos de la invalidez en la Ley de Contratos del Sector Público", Revista Documentación Administrativa. Nueva Época, n. ${ }^{\circ}$ 5, 2018. Disponible en: https://revistasonline.inap.es/index.php/DA/article/view/10608/11405 [consultado 10 de agosto de 2020].

Diez Sastre, Silvia. "Los efectos de la invalidez en los procedimientos de adjudicación de contratos públicos". En Fernando López Ramón y Francisco Villar (eds.), El alcance de la invalidez de la actuación administrativa. Madrid: INAP, 2017.

Gallego Anabitarte, Alfredo y Ángel Menéndez ReXach. Acto y procedimiento administrativo. Madrid: Marcial Pons, 2001.

García Luengo, Javier. "Los supuestos de nulidad de peno derecho establecidos al margen de la ley de procedimiento administrativo común". RAP, n. ${ }^{\circ}$ 159, 2002.

Gimeno Feliú, José María. "El nuevo sistema de recursos en materia de contratos públicos". En José María Gimeno Feliú (dir.), Observatorio de contratos públicos 2010. Cizur Menor: Civitas - Thomson-Reuters, 2011. 
Moreno Marroig, Teresa. "La ejecución del contrato tras la entrada en vigor de la Ley 9/2017". Revista Española de Control Externo, vol. XX, n. ${ }^{\circ}$ 60, 2018.

RazQuin, José ANTONIO. El impacto de la jurisprudència comunitària europea sobre los contratos púbicos (2003-2004) en el ordenamiento jurídico interno. Disponible en: file://C:/ Users/1000839/Downloads/RJ_37_II_2\%20(1).pdf [consultado el 8 de agosto de 2020].

Santamaría Pastor, Juan Alfonso. "La invalidez de los contratos públicos". En Rafael Gómez-Ferrer Morant (dir.), Comentarios a la Ley de Contratos de las Administraciones

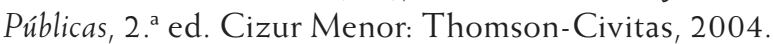

Soler Mifsud, Eva. La contratación verbal en la administración local: Efectos, procedimiento a seguir, y responsabilidades que pueden derivarse. Posible incidencia sobre la ley de transparencia y especial referencia a la Agencia de Prevención y Lucha contra el Fraude de la Comunidad Valencia. Auditoría Pública 70, 2017. Disponible en: https://asocex.es/la-contratacion-verbalen-la-administracion-local-efectos-procedimiento-a-seguir-y-responsabilidadesque-pueden-derivarse-posible-incidencia-sobre-la-ley-de- [consultado el 10 de agosto de 202].

Tardío Pato, José Antonio. "Los efectos ex tunc de la anulabilidad". Revista Española de Derecho Administrativo, n. ${ }^{\circ} 184,2017$.

\section{JURISPRUDENCIA}

Tribunal de Justicia de la Unión Europea, Sentencia de 19 de noviembre de 1991 asuntos acumulados C-6/90 y C-9/90, Rec. 1991-I 5403

Tribunal de Justicia de la Unión Europea, Sentencia de 5 de marzo de 1996, asuntos acumulados C-46/93 y C-48/93, [1996] Rec I-1029

Tribunal de Justicia de la Unión Europea, sentencia British Telecom de 26 de marzo de 1996, asunto C-392/93, [1996] Rec I-I-1631.

Tribunal de Justicia de la Unión Europea, sentencia de 29 de octubre de 2009, C-536/07, Comisión/Alemania.

Tribunal de Justicia de la Unión Europea, sentencia de 6 de octubre de 2015, Orizzonte Salute, asunto C-61/14.

Tribunal Supremo, sentencia de 31 de enero de 1994 (Aranzadi 504).

Tribunal Supremo, sentencia de 21 de junio de 1994, Casación n. ${ }^{\circ}$ 3558/1990.

Tribunal Supremo, sentencia de 31 de octubre de 1994.

Tribunal Supremo, sentencia de 30 de junio de 1997 (Aranzadi 5433). 
Tribunal Supremo, sentencia de 15 de octubre de 1997 (Aranzadi 7457).

Tribunal Supremo, sentencia de 13 de febrero de 1998 (Aranzadi 2184).

Tribunal Supremo, sentencia de 16 de junio de 1998 (Aranzadi 6322).

Tribunal Supremo, sentencia de 29 de junio de 1999.

Tribunal Supremo, sentencia de 7 de octubre de 1999.

Tribunal Supremo, sentencia de 30 de mayo de 2000.

Tribunal Supremo, sentencia de 2 de octubre de 2000, Casación n. ${ }^{\circ}$ 1546/1995.

Tribunal Supremo, sentencia de 27 de marzo de 2001.

Tribunal Supremo, sentencia de 3 de diciembre de 2001, Casación n. ${ }^{\circ}$ 2365/1996.

Tribunal Supremo, sentencia de 25 de marzo de 2002, recurso 3159/1999.

Tribunal Supremo, sentencia de 12 de abril de 2004, Casación n. ${ }^{\circ}$ 683/1998.

Tribunal Supremo, sentencia de 19 de febrero de 2008, Casación n. ${ }^{\circ}$ 43/2006.

Tribunal Supremo, sentencia de 30 de diciembre de 2008, Casación n. ${ }^{\circ}$ 5885/2006.

Tribunal Supremo, sentencia de 18 de marzo de 2011, Casación n. ${ }^{\circ}$ 1643/2007.

Tribunal Supremo, sentencia de 18 de marzo de 2011, Casación n. ${ }^{\circ}$ 1643/2007.

Tribunal Supremo, sentencia de 23 de mayo de 2012, Casación n. . 7113/2010.

Tribunal Supremo, sentencia de 2 de noviembre de 2015, Casación n. ${ }^{\circ}$ 2506/2014.

Tribunal Supremo, sentencia de 22 de junio de 2016, Casación n. ${ }^{\circ}$ 1636/2015.

Tribunal Supremo, sentencia de 23 de noviembre de 2016, Casación n. ${ }^{\circ}$ 2883/2014.

Tribunal Supremo, sentencia de 5 de julio de 2016, Casación n. ${ }^{\circ}$ 1515/2015.

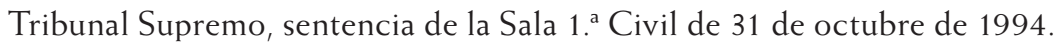

Tribunal Supremo, sentencia de la Sala 1. ${ }^{\text {a Civil de }} 27$ de noviembre de 1998, Casación n. ${ }^{\circ} 1257 / 1994$.

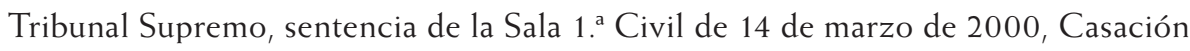
n. ${ }^{\circ} 1724 / 1995$. 
Tribunal Supremo, sentencia de la Sala 1. ${ }^{\text {a Civil de }} 26$ de julio de 2000, Casación n. ${ }^{\circ}$ 2925/1995.

Tribunal Supremo, sentencia de la Sala 1. a de 10 de abril de 2001, Casación n. ${ }^{\circ}$ 335/1996.

Tribunal Supremo, sentencia de la Sala 2. ${ }^{a}$ de 5 de abril de 2002, Casación n. ${ }^{\circ}$ 494/2001.

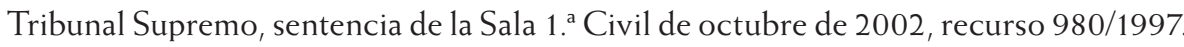

Tribunal Supremo, sentencia de la Sala 1. ${ }^{a}$ Civil de 25 de junio de 2004, Casación n. ${ }^{\circ} 2302 / 1998$.

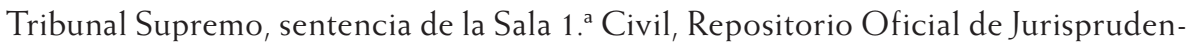
cia, STS 4648/1998.

Tribunal Supremo, sentencia de la Sala 1. ${ }^{\text {a Civil, del }} 30$ de abril de 2015, recurso n. ${ }^{\circ}$ 929/2013.

Tribunal Supremo, sentencia de la Sala 1. ${ }^{\text {a Civil de }} 23$ de noviembre de 2016, Casación n. ${ }^{\circ} 2883 / 2014$.

Tribunal Supremo, sentencia de la Sala Tercera, de lo Contencioso-Administrativo, sentencia de 3 de noviembre de 2004, recurso 2861/2002.

Tribunal Supremo, sentencia de la Sala Tercera de lo Contencioso Administrativo de 11 de enero de 2013 , recurso n. ${ }^{\circ} 462 / 2013$.

Tribunal Supremo, sentencia de la Sala de lo contencioso administrativo, de 11 de enero de 2013, Casación n. ${ }^{\circ}$ 5082/2010.

Tribunal Supremo, sentencia de la Sala Tercera de lo contencioso administrativo, de 2 de noviembre de 2015, Casación n. ${ }^{\circ}$ 2506/2014.

Tribunal Supremo de Justicia de la Comunidad Valenciana, sentencia de 21 de abril de 2006 JuR 262197.

Consejo de Estado, Dictamen n. ${ }^{\circ}$ 42123/1979, de 29 de marzo de 1979.

Tribunal Administrativo Central de Recursos Contractuales, Resolución n34/2016.

Tribunal Administrativo Central de Recursos Contractuales, Resolución 50/2011.

Tribunal Administrativo Central de Recursos Contractuales, Resolución 154/2011.

Tribunal Administrativo Central de Recursos Contractuales, Resolución 189/2011.

Tribunal Administrativo Central de Recursos Contractuales, Resolución 203/2011. 
Tribunal Administrativo Central de Recursos Contractuales, Resolución 302/2011.

Tribunal Administrativo Central de Recursos Contractuales, Resolución 180/2013.

Tribunal Administrativo Central de Recursos Contractuales, Resolución 207/2013.

Tribunal Administrativo Central de Recursos Contractuales, Resolución 220/2011.

Tribunal Administrativo Central de Recursos Contractuales, Resolución 231/2013.

Tribunal Administrativo Central de Recursos Contractuales, Resolución 237/2013.

Tribunal Administrativo Central de Recursos Contractuales, Resolución 444/2013.

Tribunal Administrativo Central de Recursos Contractuales, Resolución 514/2013.

Tribunal Administrativo Central de Recursos Contractuales, Resolución n. ${ }^{\circ}$ 190/2014 Recurso n. ${ }^{\circ}$ 084/2014 C.A. Galicia 009/2014.

Tribunal Administrativo Central de Recursos Contractuales, Resolución 301/2014.

Tribunal Administrativo Central de Recursos Contractuales, Resolución 69/2016.

Tribunal Administrativo Central de Recursos Contractuales, 103/2016.

Tribunal Administrativo Central de Recursos Contractuales, resolución n. ${ }^{\circ}$ 366/2016, de 13 de mayo de 2016, Recurso n. ${ }^{\circ}$ 279/2016.

Tribunal Administrativo Central de Recursos Contractuales, Resolución 426/2016.

Tribunal Administrativo Central de Recursos Contractuales, Resolución 418/2017.

Tribunal Català de Contractació, Resolución 49/2013.

Tribunal Català de Contractació, Resolución 39/2014.

Tribunal Català de Contractació, Resolución 188/2014.

Tribunal Català de Contractació, Resolución 127/2016.

Tribunal Català de Contractació, Resolución 23/2018.

Tribunal Català de Contractació, Resolución 24/2018.

Tribunal Català de Contractació, Resolución 35/2018. 